\title{
Reinterpretation of the Neogene sediments of the Bree Uplift, NE Belgium
}

\author{
RIK HOUTHUYS ${ }^{1 *} \&$ JOHAN MATTHIJS ${ }^{2}$ \\ ${ }^{1}$ Geoconsultant, 1500 Halle,Belgium; rik.houthuys@telenet.be. \\ 2VITO, 2400 Mol, Belgium; johan.matthijs@vito.be. \\ * corresponding author.
}

\begin{abstract}
The present geological map of the Flemish Region shows a small lens-shaped isolated outcrop of the Miocene Bolderberg, Diest and Kasterlee Formations, surrounded by younger formations, in an area that coincides with the tectonic Bree Uplift segment, on the southwestern border of the Roer Valley Graben in NE Limburg. The fault, bordering the segment at its SW side, had been interpreted to be tectonically active throughout the Neogene. Now, it is argued that an erroneous lithostratigraphic interpretation of the outcropping strata supported that view. Field observations of some of the outcrops and sampled drill holes show that the sediments do not belong to an Opitter member of the Bolderberg Formation, a Gruitrode Mill member of the Diest Formation and a Dorperberg member of the Kasterlee Formation, but most probably to the lower, latest Miocene or early Pliocene part of the Mol Formation and an unknown Pliocene marginal marine deposit not unlike and at about the stratigraphic position of the Poederlee Formation. That glauconiferous sand deposit, which has always been interpreted as consisting of two successive sedimentary cycles, is now accommodated in a single cycle, using the sedimentary model of deposition in a confined, backbarrier tidal basin subject to marine sand input and local stages of flow constriction and intraformational incision. Like already proposed by Rossa (1986) and Demyttenaere (1989), reprocessed seismic sections show only minor movements along the southwestern fault of the Bree Uplift since the Paleocene, and no inverse tectonic movements at all since the Middle Miocene.
\end{abstract}

KEYWORDS: Roer Valley Graben, sedimentary structures, flow constriction, Mol Formation, Pliocene backbarrier tidal deposit.

\section{Introduction}

The present geological map at scale 1:50 000 of the Flemish Region (Sels et al., 2001; Buffel et al., 2001; also published by the Flemish Authorities on www.dov.vlaanderen.be as the map layer Tertiair geologische kaart 1:50 000, https://www.dov. vlaanderen.be/portaal $/$ ?module $=$ verkenner $\& \mathrm{bm}=9 \mathrm{ba} 46 \mathrm{de} 1-\mathrm{f0bf}-$ 42eb-9cdf-052709aa666d) shows a remarkable feature south of the town of Bree in the province of Limburg, Belgium (Fig. 1A, B). All Neogene strata in NE Belgium dip slightly to NNE and the formation boundaries trace out more or less parallel WNWESE bands, with younger formations appearing successively to the NNE (Fig. 1B). However, near Bree, a small lens-shaped area, about $9 \mathrm{~km}$ long and $2 \mathrm{~km}$ wide, delimited by the surface trace of faults, shows a repetition of the succession of strata that occur in the south. The interpretation of this structure on the current geological map (Sels et al., 2001), known as the Bree Uplift (BU), is that it represents a narrow fault bounded block that was actively uplifted during the Neogene (Sels et al., 2001; Sintubin et al., 2001). It is a segment in the bundle of NW-SE trending faults that delimit the Roer Valley Graben (RVG) at its south-western margin (Fig. 1A, 2). NE of the faults, inside the graben (Fig. 1B), much younger strata occur, as the graben has been actively subsiding during the Neogene and Quaternary. The strata that correspond to the outcrop in the BU lie almost $200 \mathrm{~m}$ deeper inside the graben (Stainier, 1911; Legrand, 1961; Patijn, 1963; Geluk et al., 1994; Camelbeeck \& Meghraoui, 1998; Deckers et al., 2014a).

The interpretation of outcrop areas on the map relies on two main arguments.

Firstly, a deep-seated uplift snippet, called Bree Uplift (BU), has been recognized on seismic recordings. It is bounded on either side by faults belonging to the boundary fault system of the RVG (Fig. 2). Both faults dip to the NE. The northeastern fault, in this article identified as the Neeroeteren Fault (NeF), was shown to be active from Cretaceous (Bouckaert et al. 1981; Rossa, 1986; Demyttenaere, 1989; Langenaeker, 1999) to Pleistocene times (Briquet, 1907; Paulissen et al., 1985; Paulissen, 1997; Beerten et al., 1999; Beerten et al., 2018) and up to today (Camelbeeck \& Meghraoui, 1998; Vanneste et al., 2002), with normal displacements. The fault at the southwestern border of the $\mathrm{BU}$, in this article referred to as the Bree Fault $(\mathrm{BrF})$ (Demyttenaere, 1989), was argued to have experienced inverse tectonic movements, not only during the late Cretaceous and Early Paleocene, but even throughout the Neogene, implying that the bounding fault causes a discontinuity in the Neogene strata (Sels et al., 2001; Sintubin et al., 2001).

Second, the strata that crop out at the surface of the BU, near the village of Opitter in the geomorphological scarp of the RVG boundary fault and in the valley flanks of the Itterbeek brook, have been interpreted as belonging to formations that are older than those occurring outside of the BU, at the south and SW (Fig. 3A). Traditionally, three packages are recognized below the Pleistocene sand and gravel of the Plateau Terrace (Sintubin et al., 2001): (1) a 1 to $2.6 \mathrm{~m}$ thick unit of light green fine and moderately glauconite bearing sand, with at the base a pebble horizon; (2) a 4 to $5 \mathrm{~m}$ thick unit of darker green, clayey, strongly bioturbated, medium sand with at the base a gravel of pebbles and shells; (3) a unit exceeding $7 \mathrm{~m}$ in thickness of well-sorted, fine white, micaceous sand. Although all deposits are assigned to known formations, they occur in reduced thicknesses and show deviating sedimentary characteristics so that local members had to be introduced (Sels et al., 2001): (1) is the "Dorperberg member" (Zanden van Dorperberg) of the latest Miocene Kasterlee Formation; (2) is the "Gruitrode Mill member" (Zanden van de Molen van Gruitrode) of the Late Miocene Diest Formation; and (3) is the "Opitter member" (Lid van Opitter) of the Early to Middle Miocene Bolderberg Formation.

In this article, a revision of the stratigraphic interpretation is presented and the arguments leading to a Neogene structural high are challenged. The revised stratigraphic interpretation instead leads to a simpler tectonic history, in agreement with seismic evidence (Rossa, 1986; Demyttenaere, 1989; Langenaeker, 2000). The new view implies that the deposits cropping out inside the BU may actually represent late Neogene formations, younger than those shown on the geological map, which have not been recognized before in the area. A sedimentological and palaeogeographic interpretation of these deposits is presented. A list of all archived observations used in this article can be found in Table 1 (De Nil et al., 2020, this volume).

\section{Regional setting}

\subsection{Geological structure}

The BU is situated just outside the present-day RVG at its SW border (Fig. 1A). The RVG is a fault-bounded subsidence area located in NE Belgium, the SE part of the Netherlands and the adjacent part of Germany. It is bordered by the London-Brabant Massif (LBM) in the west and the Rhenish Massif (RHM) to the SE. It is the NW trending branch of the European Cenozoic Rift System (Ziegler, 1992; Michon et al., 2003). To the NW it widens and opens up to form the West Netherlands Basin (Munsterman et al., 2020). The RVG is the main structural unit of the Lower Rhine Embayment. It is flanked by the Kempen (Campine) Block (CB) in the SW and the Peel Block (PB) in the NE (Fig. 1A). Both blocks are separated from the RVG by a series of NW-SE trending normal faults, respectively the Feldbiss Fault Bundle 

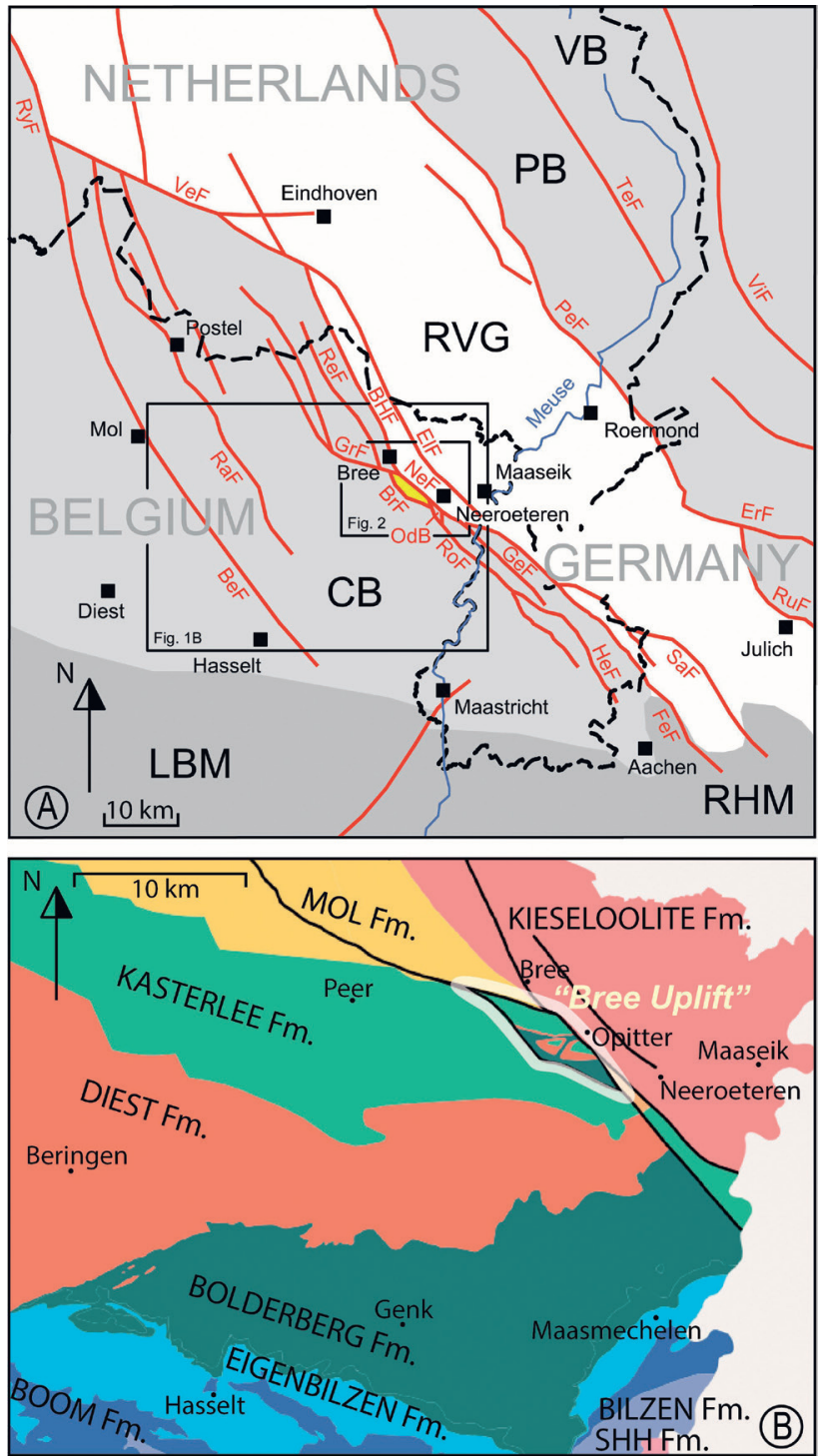

Figure 1. A. Simplified structural map of the Kempen Basin (CB) - Roer Valley Graben (RVG) area (modified after Geluk et al., 1994; Verbeek et al., 2002; Kübler, 2012; Grützner et al., 2016). Faults (red; in alphabetic order): BeF: Beringen Fault, BHF: Bocholt \& Hamont Faults, BrF: Bree Fault, ElF: Elen Fault, ErF: Erft Fault, FeF: Feldbiss Fault, GeF: Geleen Fault, GrF: Grotebrogel Fault, HeF: Heerlerheide Fault, NeF: Neeroeteren Fault, PeF: Peel Boundary Fault, RaF: Rauw Fault, ReF: Reppel Fault, RoF: Rotem Fault, RuF: Rurrand Fault, RyF: Rijen Fault, SaF: Sandgewand Fault, TeF: Tegelen Fault, VeF: Veldhoven Fault, ViF: Viersen Fault. Structural units: CB: Kempen Block, LBM: LondonBrabant Massif, OdB: Op-den-Berg Block, PB: Peel Block, RHM: Rhenish Massif, RVG: Roer Valley Graben, VB: Venlo Block, "Bree Uplift" in yellow. Location of Figure 1B and Figure 2.

B. Paleogene-Neogene geological map of the Flemish Region of the "Geologie" section of "Bodemverkenner" on www.dov.vlaanderen.be (consulted on 24 August 2020), with location of "Bree Uplift" indicated by a white outline. Fm. = Formation; $\mathrm{SHH}=$ Sint-Huibrechts-Hern.

and the Peel Boundary Fault (PeF) (Ziegler, 1992; Geluk et al., 1994). The present structure originated as a part of the incipient North Sea Rift (Dusar et al., 2001) and dates back to the early Mesozoic (Geluk et al., 1994; van den Berg, 1994). The graben started off as an area of regional subsidence that by Jurassic times gradually evolved into a fault-controlled subsiding block (Langenaeker, 1999). A thick Permian-Triassic-Jurassic sequence of sediments was deposited on top of an Upper Carboniferous basement. Due to late Cimmerian tectonics and Late Jurassic lowering of the sea level sedimentation in the RVG ceased. The Permian-Triassic-Jurassic sequence was preserved in the graben; on the adjacent blocks however Middle Jurassic to Cretaceous erosion effected a strong reduction in thickness or even a complete removal (Geluk, 1990; Geluk et al., 1994). The subsequent Late Cretaceous sediments cover an important unconformity with the underlying Carboniferous and Permian-Triassic-Jurassic strata. Due to Sub-Hercynian tectonics at the end of the Cretaceous the graben suffered inversion by compressional pulses related to the Alpine Orogeny (Rypens et al., 2004). As a result, contrary to the adjacent blocks with several hundred metres thick deposits, Cretaceous sediments within the RVG only attain an average thickness of approximately $60 \mathrm{~m}$. Inversion tectonics faded out in the Maastrichtian and Paleocene with intermittent inversion movements along faults related to the Laramide tectonic phase (Rossa, 1986; Demyttenaere, 1989; Langenaeker, 2000) and with mild flexural subsidence in the southern part of the RVG during the Early to Middle Paleocene (Deckers et al., 2014b; Deckers \& Matthijs, 2014). Contrary to the adjacent CB, the area of the $\mathrm{BU}$ was a part of the RVG up to this point, as indicated by the similar reduced thickness of the Cretaceous sediments. From here on regional subsidence resumed and clastic marine sediments were deposited until the Late Eocene in the RVG as well as on the CB and PB. During the Pyrenean tectonic phase NE Belgium and SE Netherlands underwent uplift and the related erosion removed most of the Late Paleocene and Eocene deposits in the SE part of the RVG (Verbeek et al., 2002). During the Oligocene, sedimentation resumed with deposition of marine sands and clays. At the beginning of the Late Oligocene, the RVG was reactivated as a rift basin (Michon et al., 2003) with relatively strong subsidence, mainly due to large displacements along the border faults (Deckers \& Louwye, 2019). This reactivation accelerated during the Pliocene and Pleistocene (Zijerveld et al., 1992; Houtgast \& Van Balen, 2000). In the meantime, the adjacent $\mathrm{CB}$ and $\mathrm{PB}$ experienced only minor subsidence and minor fault activity. As the RVG was located along the southern margin of the North Sea Basin, this resulted, for instance in the Belgian part of the RVG, in the deposition of up to $1230 \mathrm{~m}$ (Molenbeersel well, GSB 049W0226) of shallow marine and deltaic sediments of Paleocene, Eocene, Oligocene and Miocene age, giving way to fluvial deposits during Pliocene and Pleistocene (Luijendijk et al., 2011). The Paleogene and Neogene sediments on the BU have a thickness of only about $430 \mathrm{~m}$ (Opitter well, GSB 048E0294), similar to the deposits on the $\mathrm{CB}$. This implies that at least from the Late Oligocene on, the area of the BU did not experience the strong rift related subsidence of the RVG and functioned thus as a part of the $\mathrm{CB}$.

\subsection{Local geological structure (Fig. 1A)}

The BU is delimited to the NE by the NE-dipping RVG boundary faults. In the area SE of the BU, these faults are known as the Feldbiss Fault Bundle (Beerten et al., 1999). In the southern Netherlands this fault system consists of the Feldbiss Fault ( $\mathrm{FeF})$, the Geleen Fault (GeF) and the Heerlerheide Fault (HeF) (Patijn \& Kimpe, 1961; Patijn, 1963; Kuyl, 1971). In the area to the NW in the Belgian part of the RVG, the fault system comprises the Elen Fault (ElF), the Neeroeteren Fault (NeF) and the Rotem Fault (RoF) (Stainier, 1911; Stainier, 1931; Grosjean, 1939; Grosjean, 1949; Demyttenaere \& Laga, 1988; Demyttenaere, 1989). Although other correlations have been proposed, it is mostly thought that the RoF is the prolongation of the HeF, that the $\mathrm{NeF}$ can be correlated to the GeF and that the FeF passes into the ElF (Tys, 1980; Demyttenaere \& Laga, 1988; Demyttenaere, 1989; Geluk et al., 1994; Langenaeker, 1999; Beerten et al, 1999). However, Dusar et al. (2001) showed the FeF joins the NeFGeF through a connection called Bichterweerd scarp (Paulissen et al., 1985; Beerten et al., 1999; Vanneste et al., 2002), a bend fault near the Dutch-Belgian border. A similar lateral transfer configuration can be found further to the SE where the German Sandgewand Fault (SaF) joins the FeF near the Dutch-German border. In our study area, south of the town of Opitter, the RoF joins the NeF which forms the north-eastern border of the BU. North of the BU, the RVG boundary faults consist of the Hamont Fault (HaF) (part of the BHF in Fig. 1A), the Bocholt Fault (BoF) (Fig. 2 and BHF in Fig. 1A), the Reppel Fault (ReF) and the Grote Brogel Fault (GrF) (Paredis, 1968) which join up south of the town of Bree to form the NeF. Contrary to the vision expressed by Dusar et al. (2001), the NeF, originally defined by Stainier (1911), does not correlate with the Zuidwillemsvaart Fault ( $\mathrm{ZuF}$ ) (on Fig. 1A identical to the ElF), as it was defined in the Neeroeteren (GSB 064W0215) and Elen-I (GSB 064W0004) 


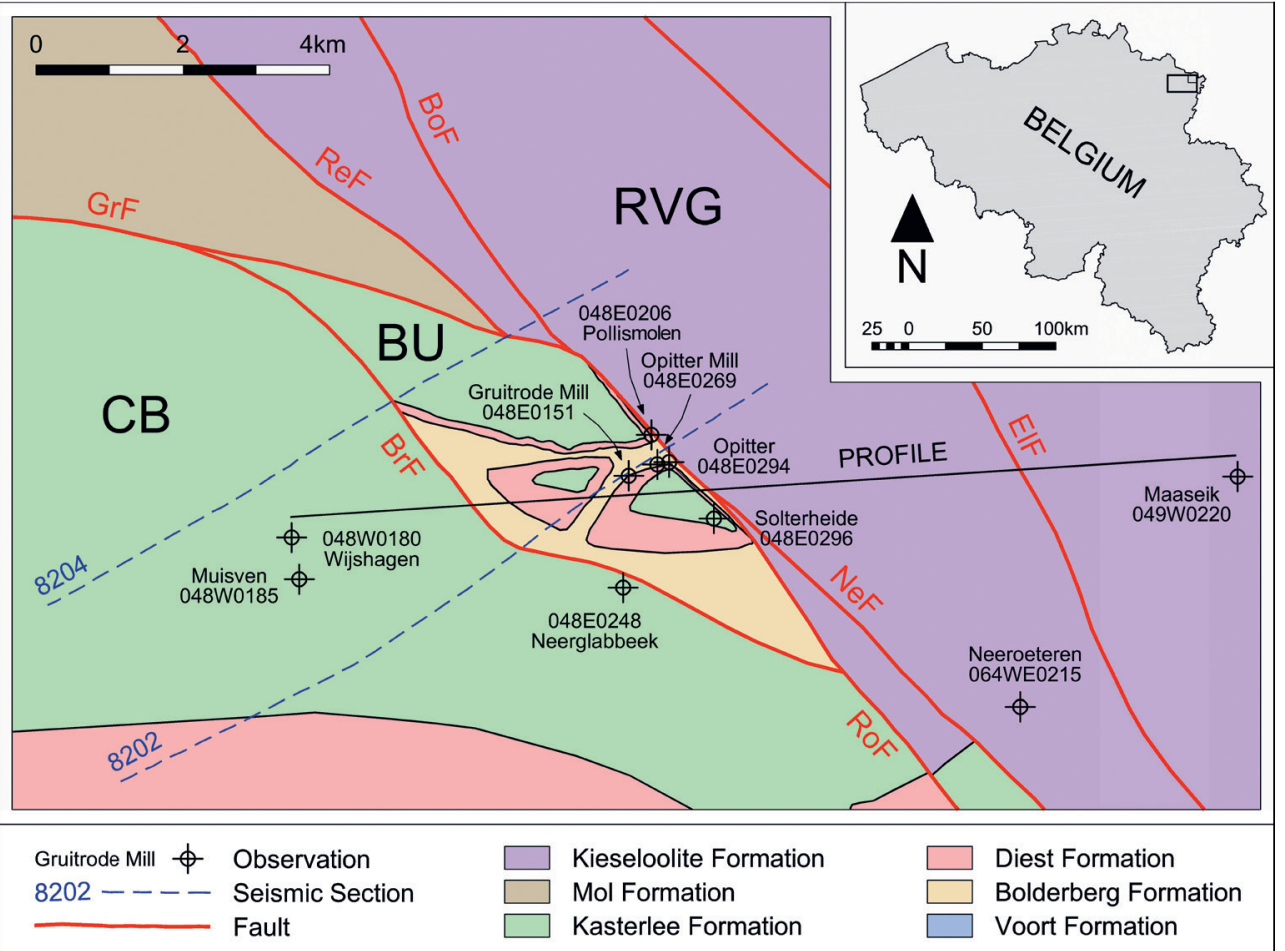

Figure 2. Local geological map (Sels et al., 2001) with location of outcrops, boreholes and seismic lines. Indication of profile of Figure 3. Seismic survey lines 8204 and 8202 (blue). Faults (red): BrF: Bree Fault, ElF: Elen Fault, BoF: Bocholt Fault, GrF: Grotebrogel Fault, NeF: Neeroeteren Fault, ReF: Reppel Fault, RoF: Rotem Fault. Structural units: CB: Kempen Block, BU: Bree Uplift, RVG: Roer Valley Graben.

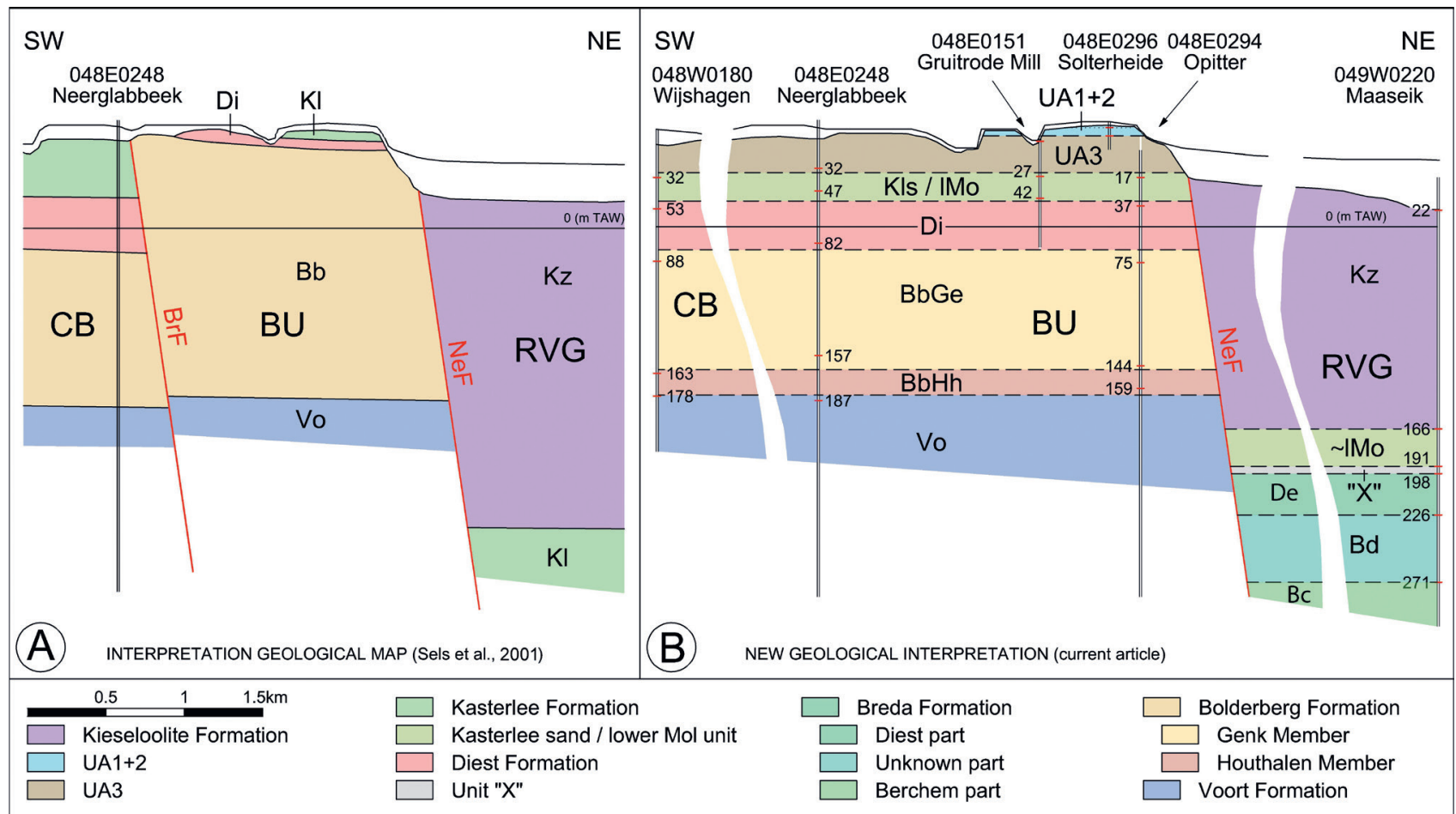

Figure 3. Cross section (location, see Figure 2) according to Sintubin et al. (2001), which corresponds SW of the Neeroeteren Fault to the present geological map interpretation (A), and (B) according to this paper. UA = Unit Assemblage (used in this paper); $\mathrm{Kz}=\mathrm{Kieseloolite} \mathrm{Formation;} \mathrm{Kl(s)}=$ Kasterlee Formation, (sandy part); $1 \mathrm{Mo}=$ lower Mol unit; $\sim \mathrm{Mo}=$ lower part of the Waubach Member, thought to correlate to the lower Mol unit; $\mathrm{Bd}=$ Breda Formation $(\mathrm{De}=$ Dessel $/$ Diest part, $\mathrm{Bc}=$ Berchem part $) ; \mathrm{Di}=$ Diest Formation; $\mathrm{Bb}=$ Bolderberg Formation; $\mathrm{BbGe}=$ Bolderberg Formation, Genk Member: $\mathrm{BbHh}=$ Bolderberg Formation, Houthalen Member; Vo = Voort Formation.

boreholes, which constrain its position approximately $2 \mathrm{~km}$ to the west of the Zuidwillemsvaart. The original $\mathrm{NeF}$ lines up with the topographical scarp at the eastern edge of the Kempen Plateau, as the Neeroeteren borehole is located right at the foot of it (Grosjean, 1942). The scarp was already recognized by Briquet (1907) as the morphological expression at the topographic surface of tectonic activity along the NeF. Somewhat confusingly, this scarp is now known as the Bree fault scarp (Camelbeeck \& Meghraoui, 1998; Vanneste et al., 2001; Vanneste et al., 2002) even though it is not related at all to the $\mathrm{BrF}$ as defined by Demyttenaere ten years earlier (Demyttenaere, 1989). Furthermore contrary to the vision expressed by Dusar et al. (2001), the BoF does not line up with the $\mathrm{ZuF}$ (Dusar et al., 2001) and further to the southeast with the ElF (Stainier, 1911). Based on the VITO-LIM07 seismic survey covering the Belgian part of the RVG, Broothaers et al. (2012) reconnected the $\mathrm{HaF}$ and $\mathrm{BoF}$ with the $\mathrm{GrF}$ to form the $\mathrm{NeF}$ south of the town of Bree, a configuration originally established by Rossa (Rossa, 1986; Demyttenaere \& Laga, 1988; Demyttenaere, 1989; Langenaeker, 2000). At its southwestern side the BU is delimited by a NE dipping fault, indicated as "fault k" by Rossa (1986) and later on named BrF by Demyttenaere (Demyttenaere, 1989; Sintubin et al., 2001; Deckers \& Matthijs, 2014).

The original definition of the BU (Bouckaert et al., 1981) was "a (Paleozoic) dome rising under a post-Paleozoic cover 
Table 1. List of exposures and boreholes near Opitter used in this study.

\begin{tabular}{llll}
\hline Location name & Observation type & GSB name and URL link & DOV name and URL link \\
\hline Elen-I & Borehole & $064 \mathrm{~W} 0004$ & $\mathrm{~kb} 26 \mathrm{~d} 64 \mathrm{w}-\mathrm{B} 5$ \\
Gruitrode Muisven & Borehole & $048 \mathrm{~W} 0185$ & $\mathrm{~kb} 18 \mathrm{~d} 48 \mathrm{w}-\mathrm{B} 186$ \\
Maaseik Jagersborg & Borehole & $049 \mathrm{~W} 0220$ & $\mathrm{~kb} 18 \mathrm{~d} 49 \mathrm{w}-\mathrm{B} 220$ \\
Gruitrode Mill & Abandoned sandpit and borehole & $048 \mathrm{E} 0151$ & $\mathrm{~kb} 18 \mathrm{~d} 48 \mathrm{e}-\mathrm{B} 153$ \\
Neerglabbeek & Borehole & $048 \mathrm{E} 0248$ & $\mathrm{~kb} 18 \mathrm{~d} 48 \mathrm{e}-\mathrm{B} 261$ \\
Neeroeteren & Borehole & $064 \mathrm{~W} 0215$ & $\mathrm{~kb} 26 \mathrm{~d} 64 \mathrm{w}-\mathrm{B} 221$ \\
Opitter Mill & Borehole & $048 \mathrm{E} 0269$ & $\mathrm{~kb} 18 \mathrm{~d} 48 \mathrm{e}-\mathrm{B} 282$ \\
Opitter Mill seismometer & Borehole & $048 \mathrm{E} 0294$ & $\mathrm{BGD048 \textrm {e } 0 2 9 4}$ \\
Pollismolen & Outcrop & $048 \mathrm{E} 0206$ & $\mathrm{~kb} 18 \mathrm{~d} 48 \mathrm{e}-\mathrm{B} 212$ \\
Solterheide sandpit & Abandoned sandpit & $048 \mathrm{E} 0296$ & $\mathrm{BGD048E0296}$ \\
Wijshagen & Borehole & $048 \mathrm{~W} 0180$ & $\mathrm{~kb} 18 \mathrm{~d} 48 \mathrm{w}-\mathrm{B} 181$ \\
Lichtaart & Abandoned sandpit & $030 \mathrm{E} 0253$ & $\mathrm{~kb} 16 \mathrm{~d} 30 \mathrm{e}-\mathrm{B} 254$ \\
\hline
\end{tabular}

virtually devoid of any Cretaceous deposits [...] that may be delimited to the south by a reverse fault $[. .$.$] which resulted from$ an uplift of downthrown blocks during the Laramide phase of orogenic deformation". The BU was considered to be a part of the Neeroeteren-Rotem Horst (Grosjean, 1949) at the SW side of the RoF. It was introduced at the occasion of a seismic survey aimed at a structural reconnaissance of the Upper Carboniferous deposits in the NE of the Kempen coal basin and its structure was supported by a positive Bouguer anomaly observed south of the town of Bree. Langenaeker $(1999,2000)$ interpreted the $\mathrm{BU}$ as a half-flower structure, partly due to reverse movements on both border faults and partly due to a pop-up effect at the restraining bend in the GrF, whereby the southwestern border fault did not exist prior to the Late Cretaceous. Along with the Op-den-Berg fault block (OdB) (Fig. 1A) to the south, the BU was seen as the result of a Sub-Hercynian dextral transpressional deformation phase acting on the boundary fault system of the RVG. Langenaeker $(1999,2000)$ did not mention any recent fault activity on the southwestern fault of the BU, nor did Demyttenaere (Demyttenaere \& Laga, 1988; Demyttenaere, 1989). Deckers \& Matthijs (2014) stated that the BU was also deformed during the Early to Middle Paleocene and that the deformation showed many similarities with positive flower structures. Due to diminishing stress-relaxation tectonics the faults on top of the BU died out in the Middle Paleocene Gelinden Member of the Heers Formation. Contrary to Langenaeker (1999, 2000), Rossa (1986) assumed important late Cimmerian normal movements along the southwestern border fault, which he interpreted as the continuation of the RoF. The major uplift was situated during the Sub-Hercynian tectonic phase when the southwestern fault acted as an inverse fault. Rossa was also the first author to give a relatively detailed geological history of the BU from the Late Cretaceous on up to the Pleistocene. He stated that the inversion faded out during the deposition of the Maastricht and Houthem Formations, at the transition of the Late Cretaceous to Early Paleocene. Later on in the Middle to Late Paleocene, with the deposition of the Heers and Hannut Formations, the BU was reactivated. Uplift also occurred during deposition of the SintHuibrechts-Hern, Bilzen and Boom Formations in the Late Eocene to Early Oligocene. Even during the Miocene a mild relative rising of the $\mathrm{BU}$ was locally observed. Based on direct field observations, (re)interpretation of borehole descriptions and lithostratigraphic arguments, Sels et al. (2001) and Sintubin et al. (2001) considered significant Miocene and Pliocene activity along the bounding faults of the BU. They suggested a continuing reverse fault activity during the Late Miocene and Early Pliocene along the southwestern boundary fault, with a displacement of up to $80 \mathrm{~m}$, and a continuing normal fault activity along the NeF up to recent times (Camelbeeck \& Meghraoui, 1998), gradually squeezing out the $\mathrm{BU}$ as a pop-up structure in the graben shoulder. However, based on high resolution reflection seismic data along the RVG boundary fault system, Dusar et al. (2001) showed there was almost no vertical displacement of the Paleogene and Neogene strata along the southwestern border of the BU. The structural high in these strata was thought to be the result of updoming rather than vertical fault displacement. Apart from this, no conclusions were drawn by Dusar et al. (2001) with respect to the outcropping Neogene deposits (Bolderberg, Diest and Kasterlee Formations) inside the BU.

\subsection{Neogene sedimentary units and palaeogeographic evolution}

The Neogene depositional history in the eastern part of the $\mathrm{CB}$ and on the BU starts with the Early to Middle Miocene Bolderberg Formation on top of the Oligocene Voort Formation. This formation is the local lateral correlate of the Berchem Formation. The base of the Bolderberg Formation is characterized by the presence of the Elsloo gravel which contains flint pebbles, rounded phosphate concretions, coarse quartz grains, shark teeth and reworked fossils, marking an important transgressive surface. It is followed by the thinly developed shallow marine glauconiferous Houthalen Member and the thicker marginal marine Genk Member. The latter consists of yellow to white fine sands which are poor in glauconite and may contain continental elements such as layers of lignite and flint pebbles. The Bolderberg Formation is truncated by a well-developed marine transgressive surface covered by the late Miocene green glauconite-rich sand of the Diest Formation (Houthuys et al., 2020, this volume). This is in turn truncated and covered by fine sand and clayey sand of the latest Miocene to early Pliocene Kasterlee Formation (Vandenberghe et al., 2020, this volume). They are shallow marine to coastal and show to the south a transition to backbarrier marginal marine deposits (Verhaegen et al., 2020, this volume). In NE Belgium, they are separated by a transgressive surface from the Pliocene Mol Formation. These white fine to medium-coarse quartz sands were also deposited in a marginal marine area, though more exposed to waves than the backbarrier facies of the Kasterlee Formation. The Mol Formation contains lignitic horizons and has dispersed small lumps or drapes of white, kaolinitic clay. The lower part of the formation may have a slight admixture of often clay-sized glauconite (Vandenberghe et al., 2020, this volume). The overall palaeogeographic evolution is from shallow marine to marginal marine.

The Neogene succession inside the RVG shows a different and thicker development, such as shown in the Maaseik Jagersborg borehole (Fig. 2; GSB 049W0220; Vandenberghe et al., 2005). Here the upper part of the Breda Formation was found at depths between 198 and $305 \mathrm{~m}$, end depth of the borehole. The Dutch Breda Formation has recently been subdivided into the 
lower Groote Heide Formation, which correlates to the Kiel and Antwerpen Members of the Berchem Formation, and the upper Diessen Formation, which is largely a lateral equivalent of the Diest Formation (Munsterman et al., 2020). The lower part of the Breda Formation found in the Maaseik borehole correlates to the upper part of the Antwerpen Member of the Berchem Formation, a fine inner shelf sand with a high glauconite content. It is followed by less glauconiferous marine fine, locally clayey sand of a facies and biostratigraphic zone not found on the $\mathrm{CB}$. The DN8 biozone was shown for the 220-272 m interval followed by DN9 for the 191-220 m interval of the Maaseik borehol e (Vandenberghe et al., 2005; Louwye \& Vandenberghe, 2020, this volume). The $235-198 \mathrm{~m}$ interval is the local correlate of the Deurne and Dessel Members of the Diest Formation. It consists of bioturbated, glauconiferous fine, sometimes clayey, sand with shells. It is succeeded by $7 \mathrm{~m}$ of brownish-white fine marine sand. Vandenberghe et al. (2005) called this unit "X" as its stratigraphic position was not clear, but recent revisions indicate it would be a lateral equivalent of the "Kempen Diest sand" (Louwye \& Vandenberghe, 2020, this volume; Houthuys et al., 2020, this volume). Unit " $\mathrm{X}$ " shows alteration characteristics possibly indicating emersion. Covering unit " $X$ " in the Maaseik borehole, a thick development of the Pliocene to Pleistocene Kieseloolite Formation is present. This is essentially a fluvial and alluvial plain deposit, with sediments of the precursors of Maas and Rhine. The lower $25 \mathrm{~m}$ of this fluvial deposit is now, based on lateral log correlations and heavy mineral analyses, assumed lateral to the lower part of the marginal marine Mol Formation (Vandenberghe et al., 2020, this volume). To summarize, the Neogene inside the RVG at Maaseik shows a more complete, shallow marine development than on the CB. It is followed by about $140 \mathrm{~m}$ of Pliocene fluvial and fluvial plain deposits, of which no equivalent is present on the $\mathrm{CB}$.

In both structural areas ( $\mathrm{CB}$ and $\mathrm{RVG}$ ) this Neogene succession is covered by Pleistocene Maas gravel, capped by fluvio-lacustrine and aeolian loam in the RVG and by aeolian sand on the $\mathrm{CB}$.

The actively subsiding RVG was probably not a differentiated sedimentary environment with respect to the $\mathrm{CB}$ during the deposition of the "Hageland Diest sand", but this changed during the transition to "Kempen Diest sand" in the upper Tortonian (Houthuys et al., 2020, this volume). From that time, the RVG was occupied by the river mouths of Maas and Rhine. The southwestern RVG boundary faults appear to have confined the river mouth area to the RVG during the latest Miocene and the Pliocene. The coeval deposits preserved on the CB testify to a marginal marine (probably lagoonal) environment. The lack of wave-created primary sedimentary structures implies a coastal barrier must have been present to the north, though where exactly is unknown. It is unclear how the palaeogeographic transition of the marginal marine environment on the $\mathrm{CB}$ to the fluvial environment in the RVG may have looked like. Some suggestions are given in this paper.

\section{Observations and interpretation}

\subsection{Outcrop observations}

In the past century, four good outcrops near the village of Opitter allowed observations of the uppermost Neogene strata: (1) Gruitrode Mill sandpit, (2) Opitter Mill sandpit, (3) Pollismolen excavation, (4) Solterheide sandpit (Fig. 2). They have been described on various occasions since the end of the 19th century. Today, only the abandoned sandpit at Solterheide allows field observations in a few small exposures. They can be combined in a complete vertical profile, though information on the lateral variations is limited. We present a sedimentary field log (Fig. 4) based on this exposure and completed by a hand drilling at Solterheide and another one at a deeper level at Opitter Mill. The strata summarized in Table 2 were found. They have been assigned an informal code number from top to bottom in this paper. The descriptions focus on lithology and sedimentary structures. The indications given of grain size are field estimates. All units from 0 at the plateau surface down to the top of unit 30 have local limonite-cemented zones. Various degrees of cementation occur in horizontal or irregularly bounded orange brown areas. In the further description and interpretation, abstraction is made of the

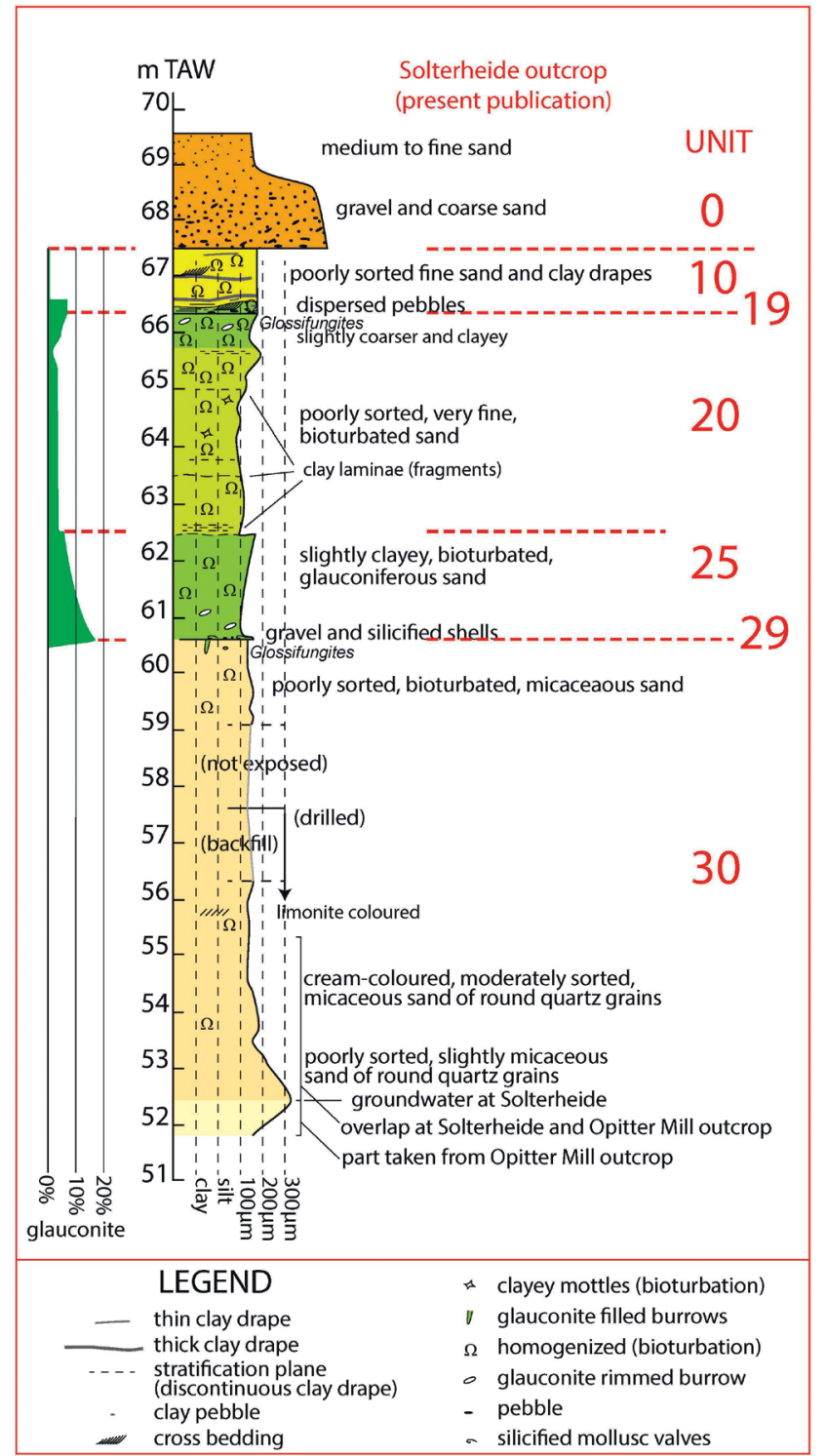

Figure 4. Field log of observations at Solterheide outcrop. Elevations in TAW (Belgian survey datum).

limonite overprinting if this is capricious or obscures primary sedimentary structures.

Unit 0: beneath a few decimetres of dark grey humiferous fine sand, of the $2.2 \mathrm{~m}$ reported in the area, about $1 \mathrm{~m}$ of red-brown medium and coarse sand, pebbles and cobbles are presently exposed in the outcrop. Some parts show pebble strata, though most of the unit seems to be homogenized. Cobbles measuring a few decimetres occur, though most pebbles are of centimetre size. They sit in a matrix of coarse, angular sand grains. The sand grains are limonite coated and the unit is partly cemented by limonite. The base is erosional. There is overall agreement that the coarse sand and gravel part represents the Zutendaal Member of the Zutendaal Formation, a braided river deposit of Mid Pleistocene age that covers the eastern half of the Kempen Plateau (Beerten et al., 2005; Beerten et al., 2018). This Maas river terrace deposit is not further discussed in this paper.

Unit 10: greyish-green to orange-brown, fine sand. The brownish areas are more or less limonite cemented. The exposures show about $1.2 \mathrm{~m}$ of this unit, which is truncated above by unit 0 or the sandpit surface. The dominant grain size is about 150-175 $\mu \mathrm{m}$, but finer-grained rounded quartz sand fractions and a small fraction of medium angular quartz grains are present. The sand is moderately to poorly sorted and is slightly clayey. It contains mica plates and a small percentage (ca. 1-2\%) of glauconite pellets in the non-oxidized areas. Internal, irregularwavy or slightly sloping contact surfaces are found (Fig. 5A). They are covered by a thin, grey (non-oxidized) clayey-sand drape. The drapes may be up to a centimetre thick. Some of the 
Table 2. Depositional strata found in the Solterheide outcrop. Strata unit codes are used in this study.

\begin{tabular}{|c|c|c|c|c|}
\hline $\begin{array}{l}\text { Unit } \\
\text { Assem- } \\
\text { blage }\end{array}$ & $\begin{array}{l}\text { Unit } \\
\text { Code }\end{array}$ & $\begin{array}{l}\text { Thickness at } \\
\text { Solterheide } \\
\text { (m) }\end{array}$ & Description & $\begin{array}{l}\text { Interpretation of the depositional } \\
\text { environment }\end{array}$ \\
\hline 0 & 0 & 2.2 & $\begin{array}{l}\text { Soil sand on red-brown coarse sand and } \\
\text { gravel }\end{array}$ & $\begin{array}{l}\text { Periglacial Aeolian coversands, overlying } \\
\text { braided river deposits (Zutendaal Gravels, } \\
\text { Beerten, 2005; Beerten et al., 2018) }\end{array}$ \\
\hline \multirow[t]{2}{*}{1} & 10 & 1.2 & $\begin{array}{l}\text { Greyish-green to orange-brown, fine, } \\
\text { slightly clayey, slightly glauconiferous sand } \\
\text { in dm-scale packages separated by mud } \\
\text { drapes }\end{array}$ & $\begin{array}{l}\text { Semi-sheltered, peri-marine environment } \\
\text { such as a tidal lagoon or shallow estuary, } \\
\text { trapping marine sediments }\end{array}$ \\
\hline & 19 & 0.05 & Thin gravel bed and dispersed pebbles & $\begin{array}{l}\text { Firmground; lag surface of peri-marine or } \\
\text { estuarine ravinement }\end{array}$ \\
\hline \multirow{3}{*}{2} & 20 & 3.85 & $\begin{array}{l}\text { Yellowish-brown to yellowish-green, } \\
\text { bioturbated, glauconiferous very fine sand }\end{array}$ & $\begin{array}{l}\text { Proximal shelf to lower shoreface of semi- } \\
\text { protected shoreline, or semi-sheltered peri- } \\
\text { marine environment }\end{array}$ \\
\hline & 25 & 1.8 & $\begin{array}{l}\text { Brownish or greyish-green, bioturbated, } \\
\text { glauconiferous slightly clayey, fine sand }\end{array}$ & $\begin{array}{l}\text { Proximal shelf to lower shoreface of semi- } \\
\text { protected shoreline, or semi-sheltered peri- } \\
\text { marine environment }\end{array}$ \\
\hline & 29 & 0.05 & $\begin{array}{l}\text { Discontinuous gravel bed with silicified } \\
\text { shells }\end{array}$ & $\begin{array}{l}\text { Firmground; lag surface of marine estuarine } \\
\text { ravinement }\end{array}$ \\
\hline 3 & 30 & $>8.8$ & $\begin{array}{l}\text { Yellowish-white, fine to medium, } \\
\text { micaceous, bioturbated sand }\end{array}$ & Shoreface of exposed shoreline \\
\hline
\end{tabular}

thicker drapes are laterally continuous over more than $10 \mathrm{~m}$, others taper out. Though largely subhorizontal, they may show a mild slope to the east, and their thickness is not laterally constant. The units bounded below by mud drapes are between less than one to a few decimetres thick. The sand between the mud drapes is homogeneous. Often, bioturbation traces and mottles can be recognized. Locally, isolated, 5 to $10 \mathrm{~cm}$ thick and about $1 \mathrm{~m}$ long cross-beds are found. They are somewhat coarser grained and contain more glauconite. The foresets dip to NE. One instance of a cross bed with foresets dipping to NE covered by a cross bed with foreset dips to SW was found. The lower 10 to $25 \mathrm{~cm}$ of unit 10 is locally coarser and contains 5 to $10 \%$ of glauconite and dispersed flint and clay pebbles. Limonite cemented cores with the print of large mollusc shell valves can be found. The sand may be either homogenized by bioturbation, or, less commonly, show cross bedding similar to the cross beds that occur higher up. This lower part of unit 10 constitutes a gradual transition to a gravel bed below, unit 19 .

Unit 19: a laterally discontinuous gravel bed at the base of unit 10. Gravelly elements include sand granules, weathered rounded flint pebbles of size $1-3 \mathrm{~cm}$, occasionally $6 \mathrm{~cm}$, broken flint fragments, and sandy clay pebbles up to $4 \mathrm{~cm}$ long. Scarce limonite-cemented shell cores occur, testifying to the original presence of now dissolved, rather large mollusc shell valves. The pebbles form no continuous pebble bed. Though most pebbles occur at the interface with unit 20 , rare pebbles are also dispersed in the overlying glauconiferous sandy base of unit 10 . The base gravel is consistently found in several outcrops at the same level in the Solterheide old sandpit, though pebbles are thinly present and may be missed if only a small outcrop would be available. The base contact surface is subhorizontal but may show irregular, sometimes wavy segments. The existing outcrop is not extensive enough to exclude there is some gentle overall slope; a levelling performed between the available exposures showed a $1 \%$ slope to WNW. Some medium-sand filled burrows descend into the underlying unit, suggesting the lower contact is a Glossifungites discontinuity surface (Fig. 5B).

Unit 20: yellowish-brown to yellowish-green, very fine to fine sand. The dominant grain size is about $100 \mu \mathrm{m}$ with moderate to poor sorting. Coarser grains of the order of $150 \mu \mathrm{m}$ are a subdominant fraction. Near the top, the mean grain size approaches $150 \mu \mathrm{m}$, while near the base the mean grain size is a little bit below $100 \mu \mathrm{m}$ and the sand is slightly clayey, i.e. the $3.85 \mathrm{~m}$ thick unit is a coarsening upwards sequence. The sand is almost completely homogenized by bioturbation. Burrows and bioturbation mottles can often be recognized (Fig. 5C). Locally, some very fine mud drape fragments are present, sometimes as single drapes, and near the base of the unit as a bunch of fine laminae or as an up to $1 \mathrm{~cm}$ thick mud layer, thus making the unit at this level slightly clayey. Some of the mud drapes exhibit slightly undulating or rippled surfaces. Overall, the unit appears to have had, before bio-homogenization, subhorizontal stratification and locally ripple cross bedding; there are often indications of plastically deformed bedding or internal interfaces (Fig. 5C, D). The unit is slightly glauconiferous (estimated glauconite pellets content between 2 and 5\%) and contains mica. The upper half metre is more glauconiferous (content 5 to $10 \%$ ) and is coarsening upwards towards a median grain size of ca. $250 \mu \mathrm{m}$ near the upper interface. This part shows $8 \mathrm{~mm}$ wide, glauconiterimmed, mostly horizontal burrows (Planolites) (Fig. 5C). Near the lower interface, the unit shows a downwards transition into a thin grey, laterally discontinuous clay layer. The lower interface represents an abrupt increase in glauconite content and grain size characterizing unit 25.

Unit 25: brownish or greyish-green, fine sand. Like in unit 20 , the mean grain size in this about $1.8 \mathrm{~m}$ thick unit coarsens upward from around 100 to $150 \mu \mathrm{m}$, but near the base, a small subpopulation of coarser $(200-300 \mu \mathrm{m})$ quartz grains is present. The content of fine, greyish-green glauconite pellets is of the order of $25 \%$ near the base but it diminishes upwards to less than $10 \%$. The sand is homogenized by bioturbation (Fig. 5E). Glauconite-rimmed Planolites occurs, just like in the top part of unit 20.

Unit 29: a laterally discontinuous gravel at the base of unit 25 . The base contains single shell valves, lying mostly with the convex side upwards (Fig. 5F); they have been silicified. Weathered flint pebbles are present at the bottom; most measure 1 to $2 \mathrm{~cm}$, but larger pebbles up to $8 \mathrm{~cm}$ occur. Several small outcrops in the sandpit exposing the basal contact of unit 25 all show this base gravel, except at one site where the base gravel is absent (Fig. 5G). The existing exposures are not extensive enough to ascertain the interface has some gentle overall slope; a levelling performed between some exposed points indicated a $1 \%$ slope to WNW. The interface with the underlying unit is a Glossifungites ichnofacies, i.e. it is a firmground. Vertical burrows descend in the underlying unit 30 and are filled down to almost $1 \mathrm{~m}$ below the interface with glauconiferous sand. 

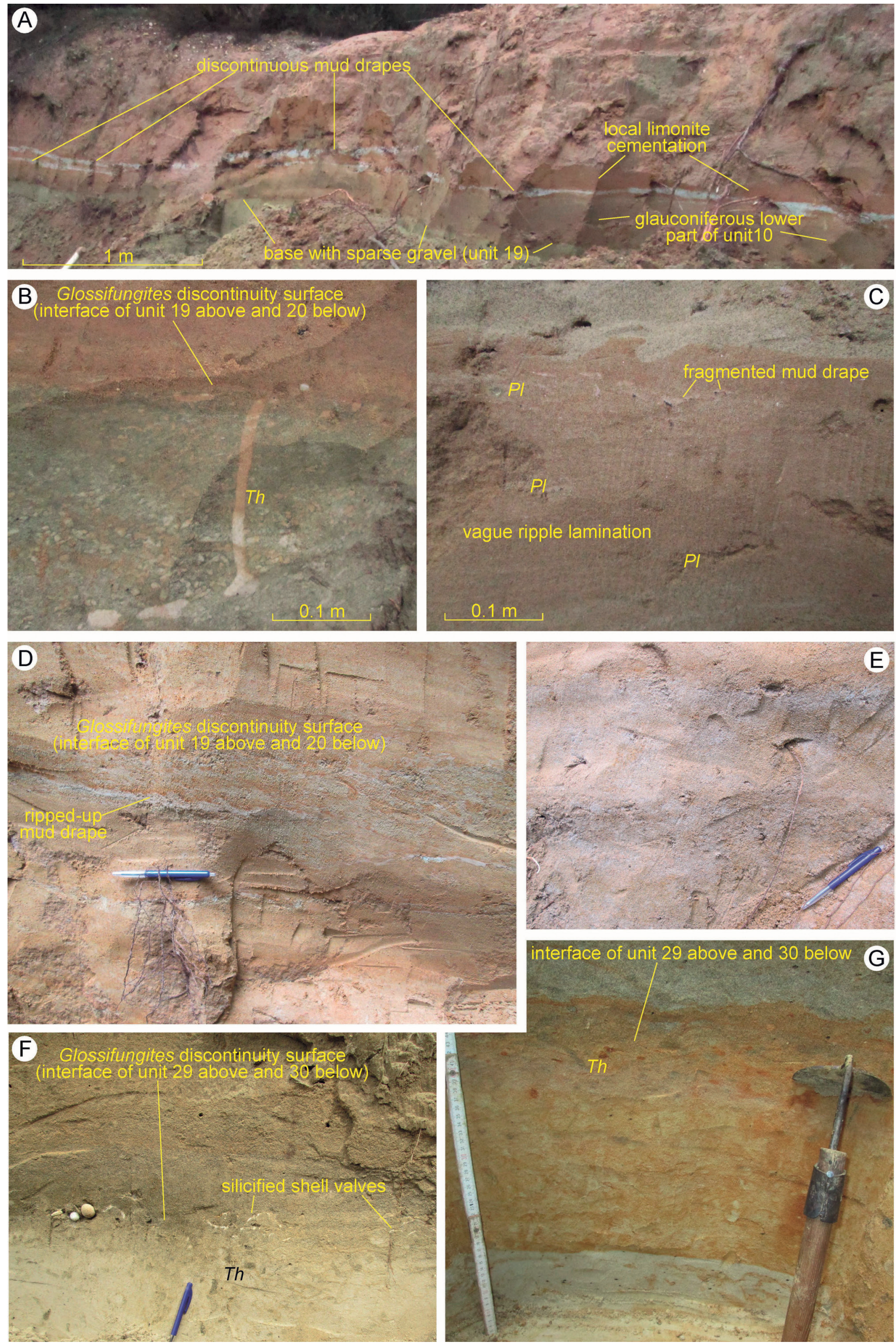

interface of unit 29 above and 30 below $\mathbf{G}$

Figure 5. Photos of sedimentary structures and details at Solterheide outcrop. Ichnofossils: $T h=$ Thalassinoides; $P l=$ Planolites. Photos A to G are from top to bottom in the outcrop; A-B are UA1, B is boundary UA1-2; C-E are UA2; F-G are boundary UA2-3. 
Unit 30: yellowish-white (some horizontal bands may be brownish due to limonite coating of the grains, Fig. 5G), moderately to well sorted, very fine to fine grained, micaceous quartz sand. The quartz grains are rounded. The top metres are exposed and show a homogenized fabric, caused by bioturbation. There is no or an extremely small content of glauconite pellets, except in the upper metre, where glauconiferous sand is present inside burrows (Fig. 5F). The mean grain size is about 100$150 \mu \mathrm{m}$ in the upper $7 \mathrm{~m}$; below that, a metre of coarsening downwards and an evolution to more poorly sorted, medium sand is observed (Fig. 4). The lower metres of the log were observed in an auger drilling carried out in the sandpit at Solterheide. The bottom of the unit was not reached. Therefore, another auger drilling was performed, this time in the abandoned Opitter Mill sandpit where the sandpit floor is at an about $1 \mathrm{~m}$ lower altitude than at Solterheide. The observations of the first $3 \mathrm{~m}$ of the drilling showed the same variations as in the Solterheide section from elevation 52.3 to $55.2 \mathrm{~m}$; therefore, the observations were projected onto the corresponding part of the log at Solterheide (Fig. 4). The following half metre showed the same sand, but now fining downward to about $150 \mu \mathrm{m}$. Like in the Solterheide quarry, the bottom of the unit could not be reached.

\subsection{Interpretation of the sedimentary environment of the deposits exposed below the Pleistocene terrace deposits at Solterheide}

Unit Assemblage (UA) 1 contains units 10 and 19. The subhorizontal morphology of the surface below unit 19, the concentration in the unit of coarse elements, including large shell valves, and the Glossifungites ichnofacies indicate an abrasion surface that removed the top of the underlying sediments belonging to UA2. The elements that constitute the gravel lag are common in the gravel beds separating the successive Neogene strata of the area. It is noted that many flint pebbles are weathered and must have been exposed on a land surface before reworking, as the broken faces are not weathered.

The basal 10 to $25 \mathrm{~cm}$ of unit 10 contains reworked glauconite and pebbles. Hydrodynamic conditions were strongly variable, with deposits testifying to waves (sand deposited from suspension) and currents (low subaqueous dunes) and occasional quiet conditions (mud drapes). The gradual upwards disappearance of reworked matter (mud and flint pebbles, probably glauconite pellets) indicates this basal part witnessed a change from high to lower energy conditions.

The remainder of unit 10 is an uncommon succession of fine sand packages, one or two decimetres thick, each time sealed by a laterally extensive mud drape. The shape of the mud drape indicates it underwent plastic deformation. It is inferred that sealing followed by burial and compaction caused upwards dewatering giving rise to deformation of the sealed sand. This sand thus had originally a loose packing. The relatively poor sorting of the fine sand deposit that contains at once very fine, clayey sand and angular medium-grain sized elements suggests a mixed energy environment. Sedimentation was nevertheless slow enough to allow (episodes of) homogenisation by bioturbation. The fine fractions suggest deposition from wave-suspended sediment, in an environment with constant but not too high wave energy. The rare, thin cross beds indicate low dunes formed under currents, probably — as thin mud drapes are also foundtidal currents. The interpretation is supported by the bimodal dip directions. The spatially extensive thin clay beds show occasional absence of waves and currents. The presence of green glauconite pellets indicates marine influence. The slightly sloping beds separated by clay laminae suggest the fill may have proceeded by lateral accretion of a large-scale, low-relief bedform, such as a sand shoal. The combination of wave action and occasional currents depositing sand packages that are bioturbated and then clay-sealed and later dewatered, is challenging to accommodate in a single environment. We suggest the depositional environment was a partly sheltered, shallow lagoon or estuary mouth. Such a setting implies that at the time of deposition a coastal barrier was present somewhere at a more distal (seaward) position. The autocyclic building and partial destruction of a coastal barrier, situated seaward of the preserved deposits, can explain the variation of hydrodynamic conditions to which the sediments testify. During times of protection against marine waves, clay deposition took place. The barrier shielding the lagoon or estuary mouth was probably often breached, allowing waves to enter the lagoon and import fine sand. The large-scale, laterally prograding bedform may represent the accretion of washover shoals or the lateral movement of a mildly sloping channel bank. The preserved thin cross beds prove the intermittent action of tidal currents, probably inside shallow channels. Unit 10 would then represent a high-stand deposit of a semi-sheltered, marginal marine environment such as a tidal lagoon or shallow estuary, trapping marine sediments, on top of an erosion surface. There are no indications of emergence of the environment.

UA2 contains units 20,25, and 29. The base of this assemblage is interpreted as a (marginal) marine or estuarine abrasion surface, associated with unit 29. Structures, gravel lag components and ichnofacies are similar to unit 19 . The overlying unit 25 has a base with coarse grains, which may be associated with the erosive basal lag deposits. The bulk of unit 25 is burrowed, glauconiferous fine sand. The schoolbook interpretation is a normal-regressive lower shoreface deposit, because of the marine elements, the ichnofacies and the coarsening upwards trend. The slightly clayey nature of the very fine sandy unit 20 seems to represent a somewhat deeper environment, such as the proximal shelf. The sudden change in grain size and lithology at the top of unit 25 represents, according to the standard interpretation, a transgressive step of a shelf shore. However, the presence of scarce mud drapes in unit 20 indicates the environment was at given times somewhat sheltered. Such sheltering combined with frequent invasions of marine waves seems to indicate deposition took place in a marine embayment. The coarsening-upwards trend of unit 20 again suggests a normal regressive setting. The upper part has been truncated by the erosion surface associated with unit 19 . There are no indications of emergence. A more comprehensive interpretation of UA1 and 2 is presented below in section 4.3., after the confrontation of our observations with the published outcrop descriptions.

Unit 30 (part of UA3, see below) shows no primary sedimentary structures. The quartz sand has been homogenized by benthic bioactivity. The grain size and complete lack of clay suggests a depositional environment subject to relatively energetic waves. The constant vertical grain-size profile suggests sedimentary aggradation kept pace with the creation of accommodation due to subsidence or sea-level rise. The coarsergrained level at $52.3 \mathrm{~m}$ TAW (Tweede Algemene Waterpassing, Belgian survey datum) is intraformational, as the grain-size changes are gradual and return to the sizes of the upper part. This level shows that variation was present in the sedimentary environment. Unit 30 would according to standard rules be interpreted as an upper shoreface deposit of a relatively exposed coast in an environment where sediment supply kept pace with the development of accommodation space. Only the upper metre was seen in outcrop. This showed no wave sedimentary structures. Therefore, this preliminary interpretation will be reconsidered below in section 4.3. by including the distribution evidence.

\subsection{Older Neogene strata beneath the Solterheide outcrop}

Mourlon (1898, p. 50; field observation also in Geological Survey of Belgium (GSB) GeoDoc records as 048E0151) describes an exposure at the Gruitrode Mill sandpit, where he completed the section by a $64 \mathrm{~m}$ deep drilling. The exposed lower $6 \mathrm{~m}$ of "sable blanc avec parties jaunâtres, pailleté" can be identified with the upper part of our unit 30 . It is continued in the drilling by $2.5 \mathrm{~m}$ below the base of the sandpit, and below this, $0.7 \mathrm{~m}$ of yellow, slightly micaceous sand with granules and pebbles of white quartz and dark grey quartzite. Below this followed $14 \mathrm{~m}$ of yellow quartz sand, similar to that above the gravelly layer, but a bit coarser. The deposits are grouped here in UA3 (Table 3). Another $5.4 \mathrm{~m}$ contained some glauconite, mica and pebbles, followed by another $0.8 \mathrm{~m}$ of the same, but now clayey sand, and $1.5 \mathrm{~m}$ and $7.0 \mathrm{~m}$ of green, glauconiferous sand (our UA4). Underneath this, $32.6 \mathrm{~m}$ of darker, more micaceous quartz sand were found, that became almost black near the bottom (upper part of UA5).

A more recent drilling was realised in 2002 in the west corner of the abandoned Opitter Mill sandpit, to install a seismometer. The first part of this $571.15 \mathrm{~m}$ deep borehole was drilled by 
Table 3. Depositional strata found in boreholes near Opitter. Strata unit codes are used in this study.

\begin{tabular}{|c|c|c|c|c|}
\hline $\begin{array}{l}\text { Unit } \\
\text { Assemblage }\end{array}$ & $\begin{array}{l}\text { Unit } \\
\text { Code }\end{array}$ & $\begin{array}{l}\text { Thickness } \\
\text { (m) }\end{array}$ & Description & Source \\
\hline \multirow{3}{*}{3} & 30 & 8.5 & Yellowish-white, micaceous fine to medium sand & Mourlon (1898, p. 50) \\
\hline & 34 & 0.7 & $\begin{array}{l}\text { Yellow, slightly micaceous sand with granules and pebbles } \\
\text { of white quartz and dark grey quartzite }\end{array}$ & Mourlon (1898, p. 50) \\
\hline & 35 & 14.0 & Pale yellow medium quartz sand & Mourlon (1898, p. 50) \\
\hline \multirow{4}{*}{4} & 40 & 5.4 & $\begin{array}{l}\text { Dark green, slightly glauconiferous sand with some mica and } \\
\text { pebbles }\end{array}$ & Mourlon (1898, p. 50) \\
\hline & 41 & 0.8 & $\begin{array}{l}\text { Yellowish-green, clayey slightly glauconiferous sand with } \\
\text { some mica and pebbles }\end{array}$ & Mourlon (1898, p. 50) \\
\hline & 42 & 1.5 & Green, slightly glauconiferous sand & Mourlon (1898, p. 50) \\
\hline & 43 & 7.0 & Green, glauconiferous sand with mica & Mourlon (1898, p. 50) \\
\hline 5 & 50 & $\sim 38$ & $\begin{array}{l}\text { Greenish fine sand, speckled with glauconite, with coarse } \\
\text { mica plates }\end{array}$ & Borehole 048E0294 \\
\hline 6 & 60 & $\sim 69$ & Grey, micaceous sand, with occasional indications of lignite & Borehole 048E0294 \\
\hline 7 & 70 & $\sim 15$ & Glauconiferous fine sand with some clay and fine shell debris & Borehole 048E0294 \\
\hline 8 & 80 & $\sim 82$ & Blackish-green and more clayey fine sand & Borehole 048E0294 \\
\hline
\end{tabular}

flushing and described in 3 or $6 \mathrm{~m}$ intervals (Dusar, GSB record 048E0294). The " 3 to $6 \mathrm{~m}$ " sample contained yellow micaceous sand and some $1 \mathrm{~cm}$ wide quartz pebbles: they may represent the unit labelled 34 in Table 3, assigned to UA3. Below this were $6 \mathrm{~m}$ of yellow sand followed by $18 \mathrm{~m}$ of pale olive-green, micaceous sand; they correspond largely to units 35 and 40 of Table 3, assigned respectively to UA3 and UA4. The following $39 \mathrm{~m}$ contained first a mixed transition and then greenish fine sand, speckled with glauconite, with coarse mica plates (UA5). It is succeeded by $69 \mathrm{~m}$ of grey, micaceous sand, with occasional indications of lignite (UA6). At about $144 \mathrm{~m}$ depth, the fine sand became glauconiferous and contained some clay and fine shell debris (UA7). This unit became blackish-green and more clayey from the depth of $159 \mathrm{~m}$ over many tens of metres (UA8). The borehole reached the top of the Boom Clay at $269 \mathrm{~m}$ depth.

The unit 35 of Table 3 (UA3) was interpreted in the borehole file as Mol Formation, units 40-49 (UA4) as Kasterlee Formation, UA5 as Diest Formation, UA6 as Genk Member of the Bolderberg Formation, UA7 as the Houthalen Member of the Bolderberg Formation, followed by UA8, the Voort Formation.

A $213 \mathrm{~m}$ deep drilling at Wijshagen located $5 \mathrm{~km}$ west of the Seismometer borehole but already outside the BU area on the $\mathrm{CB}$ was partially cored and described in detail (interpretation by Gulinck in 1964, GSB record 048W0180). Small undisturbed samples from the cores are relatively well conserved in the GSB sample storage. The Miocene part (depth 50 to $170 \mathrm{~m}$ ) of the borehole was studied for dinoflagellate cyst stratigraphy and palaeoenvironment by Louwye \& Laga (2008). The present authors visited and described the available samples, covering the 213 m length of the borehole, at the GSB on 4 April 2017. Our interpretation (Fig. 6) confirms Gulinck's original interpretation contained in the borehole file, with only a few minor adjustments to the exact depth position of the formation boundaries. It is also similar to Deckers \& Louwye's (2017) interpretation of the stratigraphy in the borehole.

Another drilling, at Neerglabbeek (GSB 048E0248), is located even closer to Opitter (about $1.5 \mathrm{~km}$ to the SW), although still on the $\mathrm{CB}$, and yielded all unit assemblages present in the Wijshagen and Seismometer boreholes. For the upper part of the subsurface, another drilling (GSB 048E0269) also located in the Opitter Mill abandoned sandpit was consulted. It appears that the five relatively deep boreholes available in the area all show the same unit assemblages at nearly the same depth (Fig. 3B). The boreholes at Wijshagen and Neerglabbeek are located outside and west of the BU; the ones at Gruitrode and Opitter Mills are inside it. In spite of this, a succession of conformal, subhorizontal strata emerges (Fig. 3B).

Immediately NE of the Opitter plateau lies the eastern part of the RVG, bounded by the $\mathrm{NeF}$ (approximate position indicated in Fig. 3). The corresponding strata in this part of the graben have been identified in the Maaseik Jagersborg borehole (see section 2.3.) and were used in the profile of Figure 3B.

\subsection{Reprocessed and reinterpreted seismic data}

A new seismostratigraphic interpretation was made of the Meeuwen-Bree (1982) and Neeroeteren-Rotem (1980-81) seismic surveys in the eastern part of the Kempen Block (CB) close to the border faults of the RVG in Belgium. Both seismic surveys were performed in order to make an assessment of the possibly exploitable coal reserves in the north of the Limburg mining district. Previous work based on these seismic surveys (Bouckaert et al., 1981; Langenaeker, 1999, 2000) concerned the Paleozoic strata. Rossa (1986) and Demyttenaere (1989) focussed on the Cretaceous and Cenozoic overburden as well. In 2003, the seismic surveys were reprocessed and at least the Paleozoic part was reinterpreted by VITO, initially in order to elucidate some apparent inconsistencies in the eastern part of the geological model of the Kempen Basin by Langenaeker (2000) and subsequently in search of deep-seated structures useful for gas and/or $\mathrm{CO}_{2}$ storage. Deckers et al. (2014a) looked at the Late Cretaceous to Early Paleocene part of the reprocessed seismic sections and later on a new seismostratigraphic interpretation was made for the Neogene-Paleogene succession in function of the revision of the geological 3D-model of Flanders (G3Dv2 on www.dov.vlaanderen.be). The Opitter borehole (GSB 048E0294), situated in the BU, is close to seismic sections 8202 and 8207 of the Meeuwen-Bree survey. The Neerglabbeek borehole (GSB 048E0248), Wijshagen borehole (GSB 048W0180) and Gruitrode (Muisven) borehole (GSB 048W0185) are located near several other seismic sections of the Meeuwen-Bree survey just outside of the BU (Fig. 2). The lithostratigraphy of these boreholes is used in the present discussion.

Based on the new interpretation of the reprocessed seismic sections it was noticed that, in agreement with the original data interpretation (Rossa, 1986; Demyttenaere, 1989) but unlike the interpretation underlying the present geological map (Sels et al., 2001), no inversion or active uplift could be recognized affecting the Neogene deposits across the BrF. Instead, all the different strata, from the present topographic surface down to the base of the Early Oligocene Sint-Huibrechts-Hern Formation, are quite 


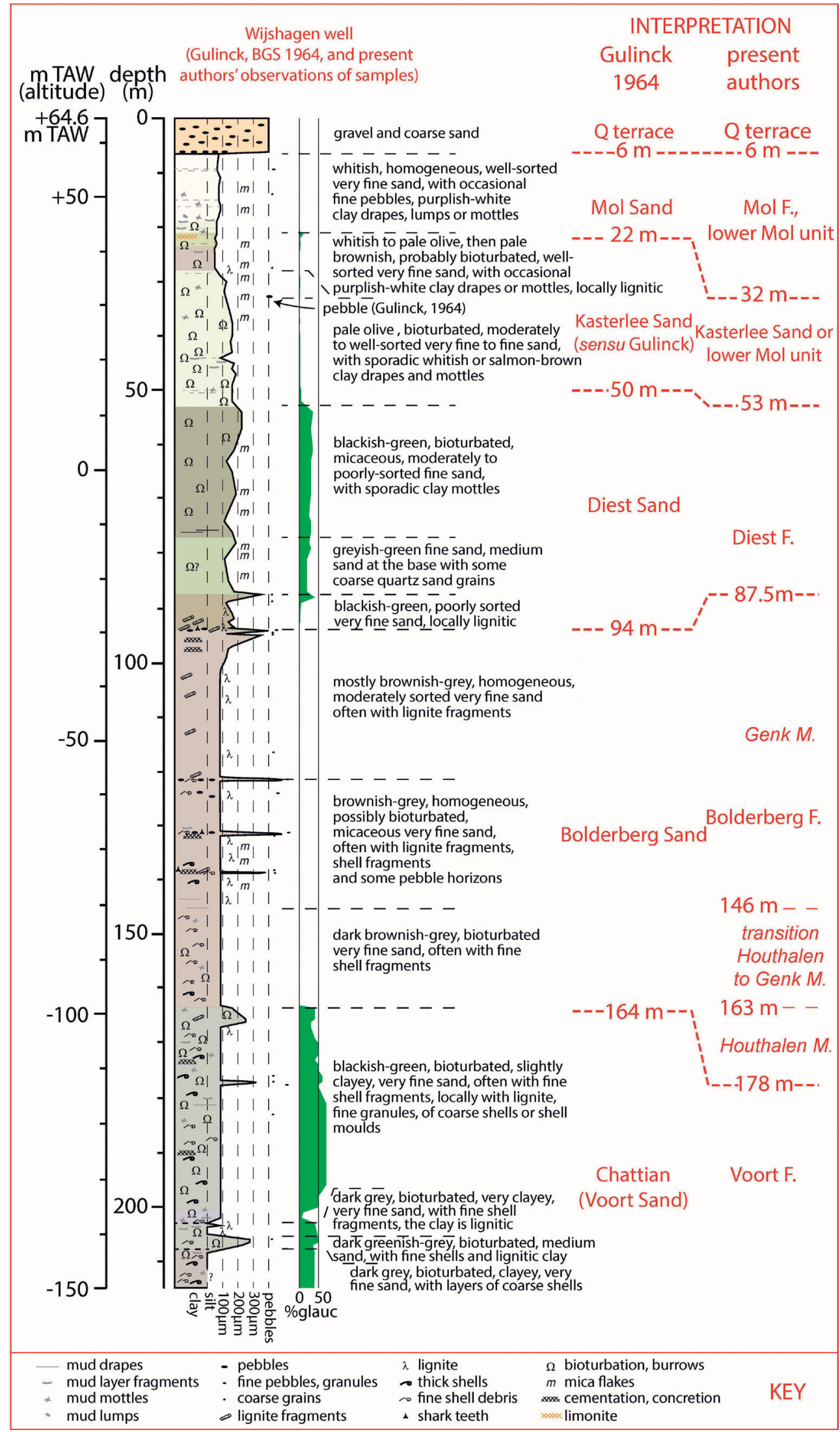

Figure 6. Descriptive $\log$ of the Wijshagen borehole (GSB 048W0180), with original and present authors' interpretation. parallel to one another and remain rather constant in thickness across the $\mathrm{CB}$ in the west, the $\mathrm{BrF}$ and the $\mathrm{BU}$, right up to the $\mathrm{NeF}$ that separates the BU from the RVG in the east (Fig. 7). Sintubin et al. (2001) ascribed this observation to the poor resolution of the upper part of the seismic sections interpreted by Rossa (1986). They did not see both interpretations as contradictory, but delivered theirs as a refinement, extending the tectonic activity of the $\mathrm{BrF}$ into the Pliocene. Nevertheless, the recently reprocessed sections exhibit a good resolution, thus allowing an interpretation with more certainty than before. They unequivocally confirm the original point of view by Rossa (1986), Demyttenaere (1989) and Langenaeker (2000).

The last deposits that appear to be affected by a vertical movement of the BU, are those belonging to the Late Paleocene Hannut Formation. Their thickness is quite significantly reduced inside the BU. Looking closer at the Paleocene units, one can see that top and base are parallel to one another (dashed black lines in sections 8202 and 8204 on Fig. 7). However, internally the different formations have boundaries that display a small angle. The Hannut Formation shows a thickening from the east on the 

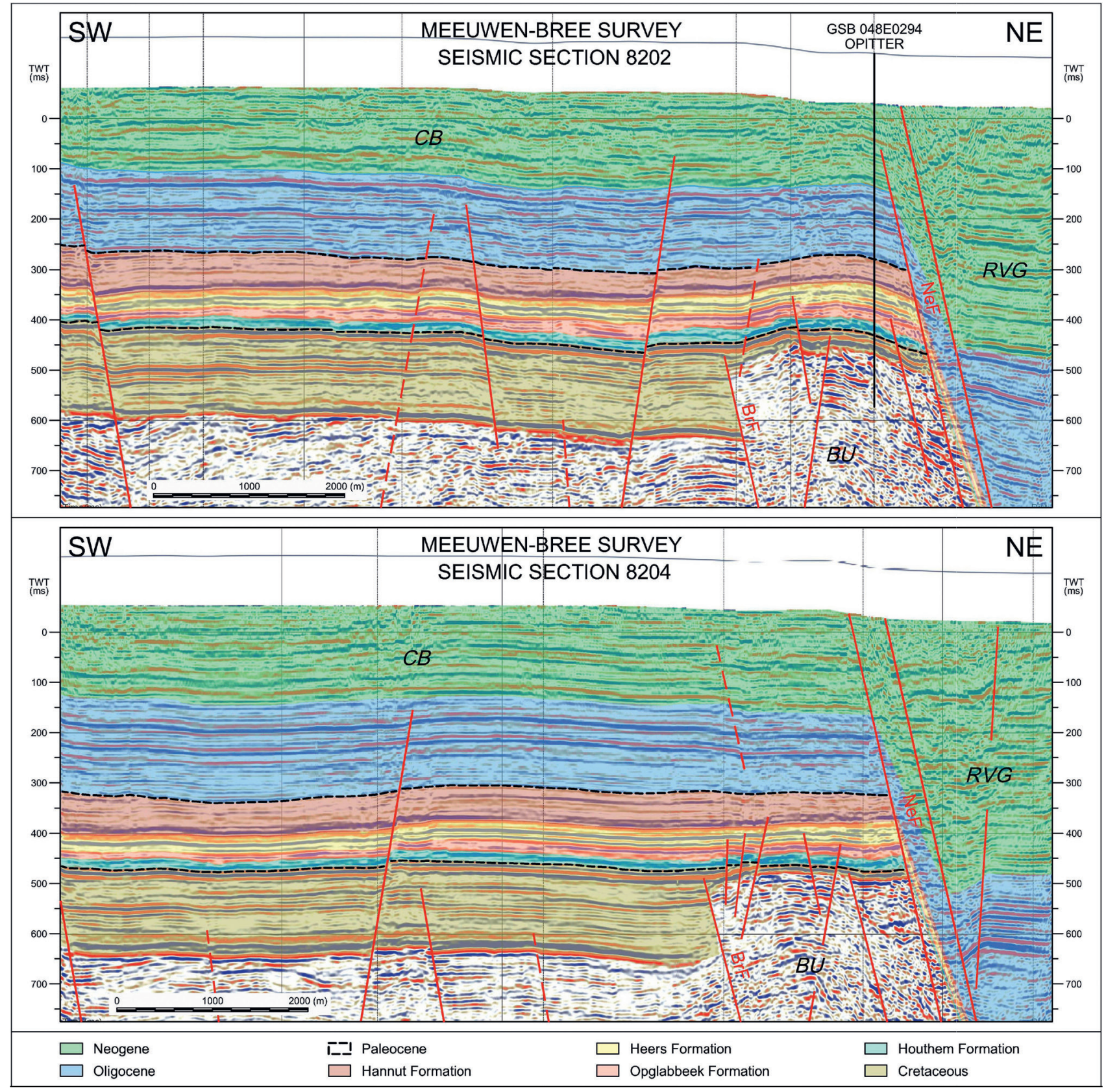

Figure 7. Seismic lines 8202 (top) and 8204 (bottom) and interpreted lithostratigraphic units.

$\mathrm{BU}$ to the $\mathrm{CB}$ in the west. This is possibly due to the large-scale tilt and uplift of the area and the accompanying erosion that occurred prior to the deposition of the Sint-Huibrechts-Hern Formation (the Pyrenean phase, Deckers et al., 2016). Due to this tectonic movement, the base of the Sint-Huibrechts-Hern Formation truncates, at the scale of the $\mathrm{CB}$, increasingly older strata from NW to SE. The older Paleocene Heers and Opglabbeek Formations however are not affected by this erosion as they remain covered by the Hannut Formation. The former show an opposite thickness development with respect to the latter, i.e. they thicken from the $\mathrm{CB}$ in the west towards the $\mathrm{BU}$ and further towards the RVG in the east. This development suggests relative subsidence of the BU compared to the $\mathrm{CB}$ during the Early to Middle Paleocene, as was already noticed by Deckers et al. (2014b) and Deckers \& Matthijs (2014) in the southern part of the RVG. This observation indicates that, prior to Late Oligocene active rifting, the BU structurally still belonged to the RVG.

An inversion of the BU may have occurred during the Pyrenean phase as all seismic reflectors correlating to the Paleocene and Cretaceous sediments show a clear upward bulging in the profiles of Figure 7. Some bulging is still seen in the base of the Oligocene deposits, at least in section 8202. The real uplift or rather inversion of the BU however is situated in Cretaceous times, prior to the Paleogene, as shown by the large difference in thickness of the Cretaceous sediments on top of the $\mathrm{BU}$ compared to the $\mathrm{CB}$ (Bouckaert et al., 1981; Rossa, 1986; Langenaeker, 1999, 2000). The fault affecting the Cretaceous strata at the southwestern side of the BU did not affect the Cenozoic strata. This does not exclude minor movements along the southwestern border of the BU later than the Oligocene. Both seismic sections clearly show slightly different features in the upper layers. Whereas on section 8202 one can still assume a slight bulging on top of the BU in the base of the Neogene deposits and even higher up, section 8204 shows just the opposite behaviour, i.e. a small step down in the base of the Neogene deposits inside the BU (Fig. 7). This feature has already been observed by Rossa (1986). His figure 28 shows the inversion along the BrF for the base of the Clastic Tertiary (the Paleocene Opglabbeek Formation) which adds up to $20.5 \mathrm{~m}$. However, his figure 29 shows no inversion along the $\mathrm{BrF}$ for the base of the Miocene deposits (Bolderberg Formation); instead it shows a normal faulting up to $10 \mathrm{~ms}$ (approximately $10 \mathrm{~m}$ ).

It results from these observations that an inverse movement of the base of the Neogene sediments of approximately $80 \mathrm{~m}$ along the BrF, as suggested by Sintubin et al. (2001) (Fig. 2), is highly improbable. The main argument for the Neogene inversion hypothesis is thus reduced to the lithostratigraphic interpretation of the outcropping sediments on the BU by Mourlon (1898) and later on by Hacquaert \& Tavernier (1946), Gulinck (GSB GeoDoc 
records 048E0151 and 048E0229, 1958), de Heinzelin (1962), Gullentops (1963) and Gullentops \& Huyghebaert (1999).

\section{Discussion}

\subsection{Correlation with published outcrop observations and lateral variations}

The authors just mentioned noted an overall similar succession of strata, but reported differing details and different strata thicknesses. We made a collage of the best field sketches next to our field $\log$ of the Solterheide outcrop (Fig. 4) in Figure 8. The relative position of the strata with respect to the lower yellowishwhite, micaceous sand and the upper terrace gravel allowed to make a lateral correlation with our units and unit assemblages. The vertical scales of the different field logs have been stretched so that a vertical metre is equal in all sketches. No clear tie to map survey datum was provided by most authors; therefore, the absolute elevations are only approximate in Figure 8.

On unit level (Table 2), it appears that correlation between the different outcrop logs is not straightforward, even though several of them were observed in the same outcrop at about the same time. Nevertheless, the cited authors are trained observers who are known to produce reliable records. Therefore it should be concluded that the variations between the observations are real and probably represent variations exposed in different faces or at different stages of the excavation works in the sandpits. Hence the correlation in Figure 8 represents only one possible interpretation; question marks show the uncertain correlations.

The base with pebbles, silicified mollusc valves and downward burrows (unit 29) was observed by most authors. Gulinck (GSB records) also observed lenses of yellowish sand (sand pebbles derived from the unit below).

The uppermost layer UA1 (units 10 and 19) is found in all outcrops in thicknesses varying from 1 to almost $3 \mathrm{~m}$. Overall, "regular" stratification is mentioned, although de Heinzelin's (1962) sketches also hint at some inclined beds. The base gravel is mentioned by all, but Gulinck (GSB records) found coarse quartz instead of pebbles at Opitter Mill.

UA2 (units 20, 25 and 29) shows more variation. While both Gulinck and de Heinzelin report inclined beds at Gruitrode Mill, only de Heinzelin hints at inclined beds (though at a milder slope angle) at Opitter Mill. The observation is by all means trustworthy. It is supported by a photo of the nearby Pollismolen outcrop published in Sels et al. (2001, their photo 4 on p. 44). Here, a ca. $0.5 \mathrm{~m}$ thick cross-bedded unit is visible at the contact of a green-and-white interbedded deposit above and a white homogeneous sand below. The cross-bedded unit shows similar colour alternations as the deposit above and incises into the white sand.

Finally, different vertical grain-size trends characterize the glauconiferous UA2: Gullentops's (1963) grain-size graph shows some fining upward in his "Diest Sand" (Gullentops \& Huyghebaert, 1999), while we observed two times coarsening upward in the corresponding units 25 and 20 at Solterheide (Fig. 4).

These considerations add to the uncertain character of the proposed lateral correlation (Fig. 8). If the inclined bedding represents an incision at the base of UA1 or 2, can it laterally be correlated with the bioturbated beds of UA2 at Solterheide? And what about the horizontally stratified beds observed by Gulinck (GSB records) and Gullentops (1963) at Opitter Mill? Only good new outcrops, where the exact nature of the larger-scale sedimentary structure can be observed, will elucidate this matter.

All authors considered their lithostratigraphic interpretation was preliminary. A variety of interpretations has been proposed (Table 4). Mainly based on Gullentops's interpretations, new lithostratigraphic members were summarised by Sels et al (2001). They are characterized as follows.

The upper marine sand (our UA1) would represent the Kasterlee Formation under a local facies, for which the new member name "Dorperberg sand" was proposed. It differs from the typical Kasterlee Sand by its high content of zircon (30 to $40 \%$ ). The middle marine sand (our UA2) is seen as a local representation of the Diest Formation, deposited outside the large Diest channel: the "Gruitrode Mill member". Its lower content of garnet and higher content of tourmaline makes it stand out from the typical Diest Sand. Finally, also the lower marine sand (our UA3) was attributed a separate member, the "Opitter member" of the Bolderberg Formation. In contrast to the other members of the Bolderberg Formation, the micaceous fine sand here has a high content of tourmaline, metamorphic minerals and zircon. It can be concluded that these lithostratigraphic assignments were based on lithological similarities but that provenance of the sediment does not really support these assignments.

\subsection{Correlation of subsurface strata}

The Wijshagen borehole gives a complete section of wellidentified strata below the units under discussion adding to the reliability of the proposed assignment to formal lithostratigraphic units of the upper deposits (Fig. 3B). We thus get, from bottom to top:

- UA7/6: confirmed Late Burdigalian to Langhian (DN4/5) age (Louwye \& Laga, 2008); UA7 correlates to the Genk Member and UA6 to the Houthalen Member of the Bolderberg Formation (Deckers \& Louwye, 2017).

- UA5: confirmed Late Tortonian (DN8) age; Diest Formation (Louwye \& Laga, 2008).

- UA4: assigned to the Kasterlee Formation (Gulinck, GSB Geodoc record 048W0180, 1964), presumably based on the fact that this is the expected lithostratigraphic position, while it shows the proper lithological characteristics: it consists of fine, micaceous sand containing a low content of pale yellowish-green glauconite, and it is locally clayey. Gulinck used to look at drilling mud colour to identify the "Kasterlee sensu Gulinck" unit, which has now been correlated to the "lower Mol" sand (Vandenberghe et al., 2020, this volume). In the present borehole, no mention was made of a change of mud colour. Note that no "clayey Kasterlee" unit was found at Wijshagen, only some clay drapes and mottles.

- UA3: lower part of the Mol Formation (Gulinck, GSB record 1964), his interpretation presumably supported by the then well-known succession in the Mol - Dessel area (Gulinck et al., 1963). This lower part is now considered part of the Donk Member (kwartszand van Mol Donk) of the Mol Formation (Gullentops \& Vandenberghe, 1995; Vandenberghe et al., 2020, this volume). The lithology of predominantly white, fine sand with scarce white, sometimes purplish, clay laminae corroborates this interpretation. The lower $10 \mathrm{~m}$ was incorporated in the Kasterlee Formation by Gulinck probably due to the low glauconite content; our interpretation places it at the base of the Mol Formation, following the latest regional interpretations by Vandenberghe et al. (2020, this volume).

Due to the correspondence in depth occurrence and lithology, the assignments of the unit assemblages to the respective formations can without doubt be extended throughout the Wijshagen to Opitter area. As the slightly lignitic top of UA6/7 was reached in most boreholes, and the strata above it consisted in all boreholes of a similar succession, there is little doubt about the correlation proposed in Figure 3B. The profile makes use of the interpretation of the relevant interval of the Maaseik Jagersborg borehole, presented in section 2.3., for the RVG part.

\subsection{Sedimentology and palaeoenvironments}

Gullentops \& Huyghebaert (1999) interpreted the depositional environment of the strata corresponding to our UA1, 2 and 3 as follows:

- UA1: "lower wave-platform" with a wave abrasion surface at its base (i.e. lower shoreface deposits)

- UA2: "deposited by strong tidal currents" in an environment "long-shore on the coastal platform near the rim of the deep Diestian submarine channel" (proximal shelf tidal dune deposits)

- UA3: "low-energy marginal marine, probably deltaic" deposits.

The data presented here imply a different interpretation.

UA3 is homogenized by bioturbation. The assemblage is characterized by the absence of suspension fractions. There are no clear primary wave or current sedimentary structures due to bioturbation. The well-rounded quartz sand is reminiscent of foreshore sand. Some grain-size variations occur in the vertical 


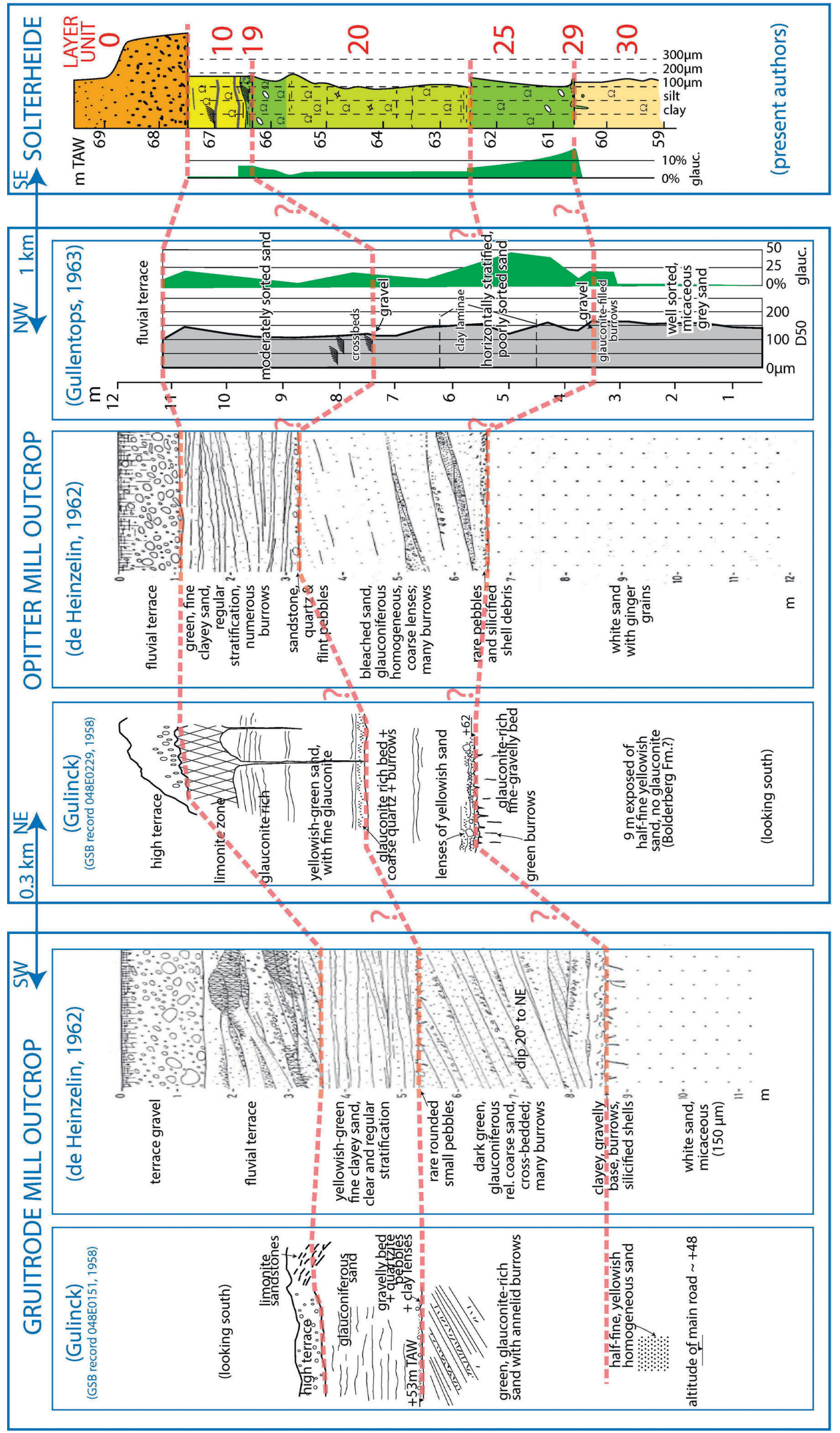




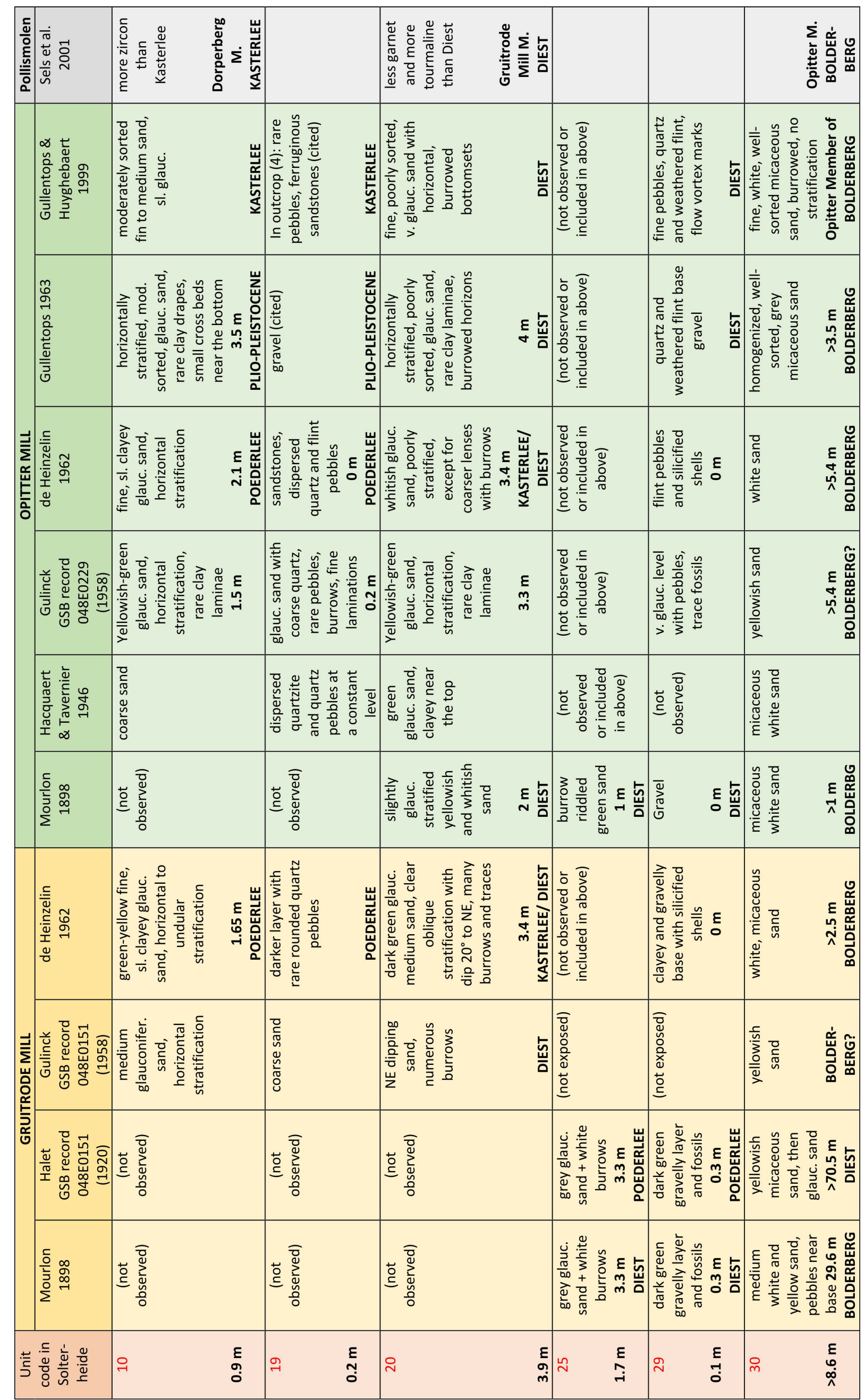


profile. These characteristics allow the same interpretation as the one proposed by Vandenberghe et al. (2020, this volume) for the lower Mol unit, to which it has been associated: a marginal marine depositional environment, like an open lagoon, where waves can supply and winnow the mostly beach-derived sand. There are no signs of tidal action. The scarce mud drapes that typify the lower Mol sand, and have also been reported for the corresponding interval of the Wijshagen borehole, were probably deposited during more sheltered phases of the lagoon. After breach of the protective barrier, waves partly rip up the mud drapes.

The small outcrops in UA1 and 2 show large-scale subhorizontal bedding ( small cross-bedded units were only found locally), often well homogenized by bioturbation, that would following standard interpretation rules suggest two successive deposits of shallow inner nearshore, relatively sheltered shelf environments. However, the confrontation to all available evidence indicates this interpretation does not accommodate all facts. A simple stacking of two marine cycles would lead to sedimentological and hydraulic inconsistencies, as it would not explain the inferred juxtaposition (see Fig. 8) of the inclined strata reported by de Heinzelin (1962) and Gulinck (GSB records) at Gruitrode Mill, the cross stratification exposed at Pollismolen (Sels et al., 2001), the mildly sloping strata at Opitter Mill described by de Heinzelin (1962) and the subhorizontal strata reported in the same outcrop by Gulinck (GSB records) and Gullentops (1963) and now also reported at Solterheide. It is further observed that the lithological elements and the set of small-scale depositional structures found in UA1 and 2 are very similar. The same applies to the elements found in both base gravels 19 and 29.

De Heinzelin (1962) measured a foreset dip of $20^{\circ}$ to $\mathrm{NE}$ at Gruitrode Mill. The photo of inclined strata at the contact of the lower white and upper glauconiferous sand at Pollismolen (Sels et al., 2001) allows to observe (1) the cross stratification is not the typical cross bedding associated with large dune progradation: the foreset slope is milder, and (2) the inclined strata exist of alternating packages of yellowish-white sand and green (glauconiferous) sand. The first observation implies the cross stratification is probably associated with the lateral movement of a channel bank (inner bend accretion) while the alternate layers seem to consist of both substratum derived (yellowish-white, UA3) and environment derived (glauconiferous, UA2) sand.

This is only possible if the erosion associated to the channel dynamics was intraformational, at least with respect to UA2. Provided the large-scale bedding occurring elsewhere in UA2 has a mild slope and so would indicate an internal progradational architecture, the intraformational erosion and fill may have taken place as the consequence of the basin fill process itself. A preliminary model is presented here that accommodates the observations, exploits the fact that lithological elements and depositional features are shared by UA1 and UA2, and explains why the unit assemblages have been perceived as separate, successive depositional cycles.

The overall master bedding of both UA1 and UA2 seems subhorizontal, yet may have a very mild slope such as our levelling pointed out in the Solterheide outcrop. There, the master bedding slope is at right angles to the palaeocurrent direction indicated by the local small cross beds. This implies a lateral progradation with respect to the current direction. Lateral fill of a confined marginal marine basin, such as a lagoon, inlet or estuary, may give rise to flow constriction occurring in the (local) end stages of the fill.

Flow constriction is the increase of flow velocity due to a decrease of flow section, in a situation where the amount of water passing through the section remains constant. Such conditions are fulfilled in semi-enclosed backbarrier tidal basins: the same amount of water that enters from the sea into the basin during high tide over its entire width (including the intertidal flats) has to leave it during low tide. The sand that is entrained into the semi-enclosed basin during flood, gives rise to sedimentation, lateral progradation of one shore of the flow channel, and finally a decrease of the ebb flow sections. During flow constriction, a vertical incision into the fresh deposits and finally even down into the substratum may occur, causing local reworking of both types of sediment. Flow constriction associated to high-stand lateral fill of a confined basin was proposed as the mechanism of intraformational scour and fill with large cross beds in the Brussels Sand (Houthuys, 2011) and the Diest Sand (Houthuys \& Matthijs, 2018), be it at scales that gave rise to incisions of a larger order of magnitude.

Intraformational erosion associated to lateral fill of a confined basin is one possible sedimentary model to explain the observations. The model is at this stage hypothetical. Good observations of large-scale bedding planes are needed to discard or confirm it. At this stage, it is even not clear in which direction the large-scale beds dip, and thus no statement can be done about the internal younging direction inside the deposit.

The model is nevertheless thought to be a valid candidate to describe the true sedimentary history and is therefore further detailed (Fig. 9). After the deposition of the yellowish-white lagoonal sand of UA3, and prior to the deposition of UA1 and 2, a low relative sea level is thought to have occurred, during which the upper part of UA3, which was probably topped by a beach deposit with incorporated land-derived pebbles, would have been eroded. Assumedly, during the low relative sea stand, an overland drainage system had developed with water courses having their mouth in the sea not too far to the north and NE, in the RVG. The overland drainage system probably introduced a supply of land-derived, relatively coarse and angular elements into the environment. During subsequent relative sea-level rise, the sea invaded the deepest sections of the river system and wave abrasion possibly widened the basin so that some of the interfluves disappeared. This marine invasion is thought to have created a confined marginal marine environment such as a tidal lagoon or a small estuary. Here, a hydrodynamically mixed regime of tidal currents and waves may have existed. They may, in the initial stages of the transgression, have further eroded the substratum (combined tidal and wave ravinement surface; first adaptation of the basal erosion surface after transgression).

It is remarked here that the presence of a marine environment not too far to the north or NE of the outcrops near Opitter, and very likely at times separated from it by a coastal barrier, is inferred purely from the sedimentary observations in the outcrops, without linking it to a particular area or time window.

As soon as the accommodation space was created, also the import and reworking of local sediments started. The model proposes a lateral accretion, where one bank of the confined inundated area prograded laterally into the basin, thus reducing its subtidal extent. This can be the result of a sand supply path that entered the confined, marginal marine basin from one side.

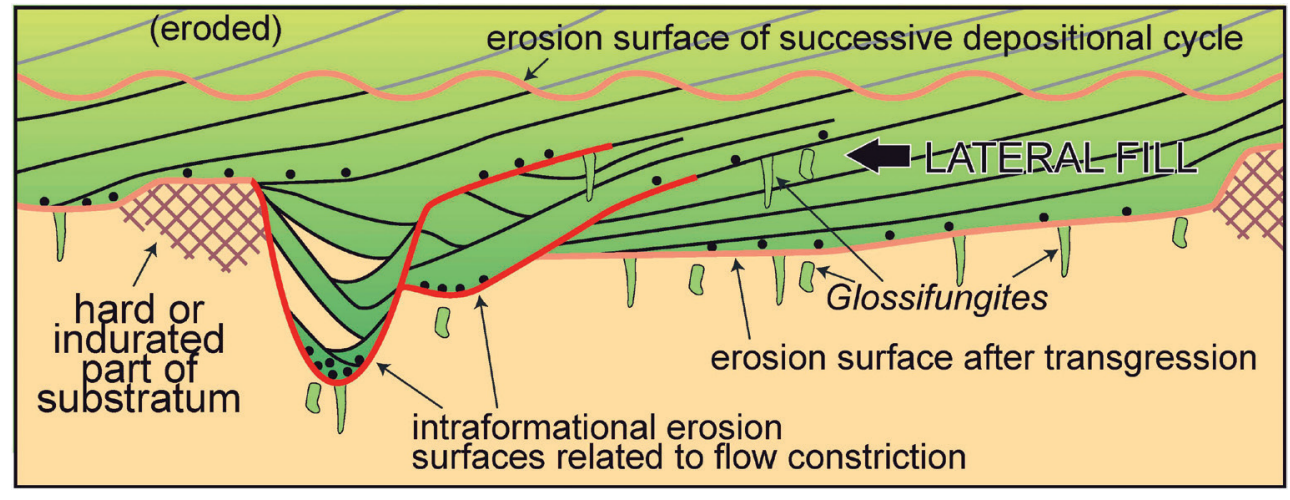

Figure 9. Sketch illustrating the sedimentary model proposed for the deposition of UA1 and 2, based on the succession observed in the Solterheide sand pit. 
A likely candidate is the sand stream of the littoral drift. As only the deepest part of this fill has been preserved, the bedding planes observed in outcrop near Opitter would represent the very mildly sloping bases of the laterally accreting bank. Due to the mixed supply of littoral sand and land-derived clastics, the deposits of UA1 and 2 are poorly sorted. Occasional quiet conditions, such as temporal damming of the confined basin by a beach barrier, may explain the clayey intercalations that seal some of the master beds.

It is assumed that the transgression surface was not flat, but contained palaeohighs. They may be local chunks of the pretransgression land surface, preserved during the transgressive erosion, because they were more sheltered or more erosionresistant due to soil processes or incipient cementation. When the lateral fill reached such a palaeohigh (Fig. 9), a local flow channel or scour trough may have incised in both the already deposited base of UA2 and the substratum. This incision mechanism creates intraformational erosion surfaces, which constitute a second, local readjustment of the original basal erosive surface (see Fig. 9). These subtidal incisions can adopt the shape of localized, elongated troughs of which the deepest part is (slightly or much) deeper than the original erosive surface.

This depositional model explains at once

- the observation of incised beds of cross-stratification consisting of alternating laminae of UA3 substratum sediment and sediment from the basal part of UA2;

- the presence of a cross-stratified incision fill lateral of subhorizontal, bioturbated beds;

- the occurrence of at least one repeated pebble layer at higher levels composed of the gravelly elements of the base;

- the vertical dispersion of the pebbles at that higher level inside a sand matrix;

- the different thicknesses observed in different outcrops of the units belonging to UA1 and 2 .

Each intraformational scour was presumably rapidly filled, almost as soon as it was created. This explains the relative scarcity of bioturbation traces in the cross-stratified beds. The presence of Glossifungites ichnofacies both at the transgressive surface and at the base of intraformational erosion surfaces imposes no time constraints. The ichnofacies may develop rapidly and may develop autocyclicly (MacEachern et al., 1992, 2007). After each event of intraformational scour, the main depositional process of lateral progradation simply rolls over the scour fill and continues to fill the embayment.

If valid, the model implies that UA1 and 2 actually belong to one depositional cycle. There would also be the following implications regarding the geometry and extent of UA1 and 2:

- UA1+2 are incised in the underlying deposits;

- UA1+2 represent the deposit of a partly sheltered, backbarrier tidal lagoon or embayment, tributary to a tidal sea in the $\mathrm{N}$ and NE;

- The spatial extent of UA1+2 deposits is limited; often only the truncated, lower part of a tidal lagoon or embayment fill is preserved. The extent is likely a reflection of the assumed incised valley system developed during the regression between the deposition of UA3 and UA1+2

- UA1+2 represent a backbarrier correlative of a marine deposit further $\mathrm{N}$ and NE that remains to be identified. This is logically situated in the nearby RVG. It must have invaded the then fluvial RVG from the NW, may have been shallow, related to a sea-level fluctuation only, and its sediments may have been removed by river processes during a subsequent low sea-level phase.

In conclusion, we interpret UA1 and 2 as a depositional package belonging to one sedimentary sea-level cycle. The environment was a partly sheltered tidal lagoon or embayment most probably filling a drowned and eroded incised valley system. Given the modest observed thickness of UA1+2, less than $10 \mathrm{~m}$, the incision was likely only $10-15$ metres deep and may have been triggered by a normal, low-amplitude relative sea-level drop occurring in the interval between the deposition of $\mathrm{UA} 3$ and $\mathrm{UA} 1+2$.

\subsection{Implications for the local lithostratigraphy}

All sufficiently deep boreholes at the $\mathrm{CB}$ and BU side of the NeF find similar strata at more or less the same depth (Fig. 3B). Inside the RVG, east of the $\mathrm{NeF}$, the corresponding unit assemblages are at depths about $175 \mathrm{~m}$ lower than west of the border fault.

$\mathrm{UA} 1+2$ and 3 pose a geographical challenge. The marginal marine (open lagoon) deposit of UA3 is only found on the CB and BU. It is stratigraphically juxtaposed to fluvial deposits inside the RVG. Either the border fault was a geographical boundary at the time of deposition, with a braided river present inside the $\mathrm{RVG}$, or the fluvial environment postdates the marginal marine facies preserved on the $\mathrm{CB} / \mathrm{BU}$ and had sufficient erosive power to remove the equivalent of the marginal marine facies inside the RVG.

The deposits of UA1+2 are inferred to fill an incision with a vertical dimension of around $10-15 \mathrm{~m}$, typically the vertical range of small third-order sea-level cycles. The inception of incision is situated during the low sea level preceding the sedimentation cycle, when rivers incise their valley. As no fluvial sediments are found in $\mathrm{UA} 1+2$, it is suggested that the marine invasion during subsequent sea-level rise removed and partly reworked any fluvial sediments and started to import sediments with a marine provenance. A confined marginal marine environment (lagoon, tidal inlet, estuary...) got installed. The process of lateral accretion in that confined basin gave rise to events of flow constriction and local intraformational scour. The patches of $\mathrm{UA} 1+2$ preserved on the BU thus allow to infer the presence of an open marine environment not too far from the outcrop, most logically in the RVG. No marine deposits are known in the succession above "unit X" in the Maaseik borehole. It is reasoned that at the lowstand following the deposition of UA1+2 a fluvial environment was reinstalled inside the RVG, and that the braided river known to have occupied the area during the latest Miocene to Pleistocene (Vandenberghe et al., 2005) has removed the possibly thin marine deposits that would correlate to UA1+2.

It is a matter of speculation to correlate the exposed glauconiferous sands near Opitter $(\mathrm{UA} 1+2)$ to a marine formation known in the northern Kempen. Mourlon (GSB Geodoc record 048E0206, 1896) assigned to the Poederlee Sand (upper Pliocene) a $0.1 \mathrm{~m}$ thick glauconiferous, indurated, fossiliferous layer just below the Pleistocene gravel at the Pollismolen outcrop. Halet (GSB Geodoc record 048E0151, 1920) suggested "Poederlee" for UA2 (Table 4). The type section of that formation is in an abandoned sandpit at Lichtaart (GSB Geodoc 030E0253), described by Gulinck (1960), de Heinzelin (1962), Gullentops (1963) and Gullentops \& Huyghebaert (1999). The outcrop can still be visited; the present authors studied there the lithological variation and sedimentary structures. Also information was obtained from a temporary 2012 outcrop from the N19g road bypass of Kasterlee (N. Vandenberghe, M. Schiltz, K. Beerten, pers. comm., 2017), where the same strata as at Lichtaart were exposed. There are remarkable similarities between the Poederlee Formation such as exposed at Lichtaart and Kasterlee, and UA1 and 2 exposed near Opitter:

(i) a similar lithology: quartz grains of similar size and shape, a relatively high but variable glauconite pellet content, presence of mud drapes;

(ii) the probable occurrence of incised channels or troughs near the base;

(iii) the presence of a base gravel with rounded flint pebbles and reworked, silicified shells;

(iv) slightly cemented whitish sand pebbles near the base;

(v) the general bedding style with overall low gradients possibly indicating lateral accretion surfaces;

(vi) similar sedimentary and trace fossil structures;

(vii) similar ghosts of shell valves;

(viii) similar flow directions indicated by rare cross-bedded units.

At the same time, the proportions of the heavy mineral components are different (Gullentops 1963; Gullentops \& Huyghebaert, 1999; Sels et al., 2001). However, heavy mineral fingerprinting of the different marine and marginal marine Neogene (and Paleogene) sediments is not straightforward as the successive deposits contain cyclic returns of provenance area and/or significant amounts of reworked sediment (Verhaegen et al., 2019). Moreover, the outcrops near Lichtaart and Opitter are 
both at strongly weathered sites. Chemical weathering affects the heavy mineral assemblages, creating differences to unweathered equivalents.

We think a correlation of UA1 and 2 with the upper Pliocene Poederlee Formation is possible. The main argument to support this is the similar depositional style of the units near Opitter and at a similar level in the regional Neogene lithostratigraphy. The main difficulty is having an upper Pliocene marine incursion penetrating this far to the southeast, about $45 \mathrm{~km}$ from confirmed Poederlee Formation outcrops. A marine incursion inserted in younger fluvial deposits, such as the Pleistocene Stramproy Formation (Dusar et al., 2012), is therefore even more unlikely. The suggested correlation of UA1 and 2 to the Poederlee Formation needs additional evidence. It is hypothetic at this stage.

In order to elucidate the nature of the lateral variations inside the upper marginal marine strata once well exposed near Opitter, it is recommended to refresh a few sufficiently large sections of the abandoned sandpits. The local and regional stratigraphy would greatly benefit from a new cored drilling situated on the Kempen Plateau east of the Itterbeek valley near the Solterheide sandpit to a depth of about $100 \mathrm{~m}$.

\section{Conclusion}

It has been demonstrated that the Neogene strata occurring in the upper subsurface (order of 100-200 m) of the NE edge of the Kempen Plateau, south of Bree (Limburg, Belgium), show no difference in depositional style or tectonic deformation across the SW border of the Bree Uplift (BU). Probably, only minor movements occurred along the Bree Fault $(\mathrm{BrF})$ up to the late Eocene (Pyrenean phase). There is no conclusive evidence of any inverse tectonic movement during the deposition of the upper Miocene Diest Formation and younger strata. The hypothesis of a Neogene tectonic activity along the BrF, i.e. a nearly continuous inverse fault activity resulting in an uplift of about $80 \mathrm{~m}$ during late Miocene and early Pliocene times, such as put forward by Sintubin et al. (2001), in function of the new geological map (Sels et al., 2001), is here challenged and should be abandoned.

According to the views and hypotheses expressed in this paper, the uppermost Neogene strata that are exposed just south of the town of Opitter, have wrongly been assigned to the Miocene Bolderberg, Diest and Kasterlee Formations (Sels et al., 2001). The present authors argue that the yellowish-white sand below the contact surface at about TAW $+60.5 \mathrm{~m}$ in the abandoned Solterheide sandpit is part of the Donk Member of the Mol Formation, while the two packages of glauconiferous sand found above that surface belong to one depositional cycle, instead of two cycles such as proposed by descriptions and interpretations up to now. They are interpreted as the fill of a confined marginal marine tidal basin, protected by a coastal barrier from the open sea. Pending further evidence, it is suggested that the glauconiferous sandy deposit might represent a local outlier of the upper Pliocene Poederlee Formation

\section{Acknowledgements}

We are indebted to Michiel Dusar and Dirk Munsterman for a thorough review with many comments that helped improve the quality of our publication.

\section{References}

Beerten, K., Brabers, P., Bosch, P. \& Gullentops, F., 1999. The passage of the Feldbiss Bundle through the Maas Valley. Aardkundige Mededelingen, 9, 153-158.

Beerten, K., Vandenberghe, N., Gullentops, F. \& Paulissen, E., 2005. Toelichting bij de Quartairgeologische kaart [van België, Vlaams Gewest]: kaartblad 18 - 10, Maaseik [- Beverbeek] [1/50 000]. Vlaamse Overheid, Dienst Natuurlijke Rijkdommen, Brussel, 48 p.

Beerten, K., Dreesen, R., Janssen, J. \& Van Uytven, D., 2018. The Campine Plateau. In Demoulin, A. (ed.), Landscapes and Landforms of Belgium and Luxembourg. Springer, Cham, World Geomorphological Landscapes, 193-214. https://doi.org/10.1007/978-3-319-58239912

Bouckaert, J., Dusar, M. \& Van de Velde, E., 1981. Exploration for coal in the Neeroeteren-Rotem area (Campine coalfield of the CampineBrabant Basin NE Belgium): Preliminary results of a seismic survey carried out in December 1980 - January 1981. Annales de la Société géologique de Belgique, 104, 281-289.

Briquet, A., 1907. La vallée de la Meuse en aval de Liége. Bulletin de la Société belge de Géologie, 21, 347-364.

Broothaers, M., Deckers, J., Lagrou, D. \& Matthijs, J., 2012. 3D-lagenmodel van de Tertiaire afzettingen in de Roerdalslenk in Vlaanderen. VITO, Mol, VITO-rapport 2012/SCT/R/191, 58 p.

Buffel, P., Claes, S. \& Gullentops, F., 2001. Toelichtingen bij de geologische kaart van België, Vlaams Gewest:kaartblad 26, Rekem [ $1 / 50$ 000]. Belgische Geologische Dienst en Ministerie van de Vlaamse Gemeenschap, Afdeling Natuurlijke Rijkdommen en Energie, Brussel, $56 \mathrm{p}$.

Camelbeeck, T. \& Meghraoui, M., 1998. Geological and geophysical evidence for large palaeo-earthquakes with surface faulting in the Roer Graben (northwest Europe). Geophysical Journal International, 132, 347-362. https://doi.org/10.1046/j.1365-246x.1998.00428.x

Deckers, J. \& Louwye, S., 2017. A reinterpretation of the ages and depositional environments of the lower and middle Miocene stratigraphic records in a key area along the southern margin of the North Sea Basin. Geological Magazine, 156/3, 525-532. https://doi. org/10.1017/S0016756817000991

Deckers, J. \& Louwye, S., 2019. Late Miocene increase in sediment accomodation rates in the southern North Sea Basin. Geological Journal, 55, 728-736. https://doi.org/10.1002/gj.3438

Deckers, J. \& Matthijs, J., 2014. A late Danian change in deformation style in the south-eastern part of the Campine Basin. Geologica Belgica, 17/3-4, 236-243.

Deckers, J., Vernes, R., Dabekaussen, W., Den Dulk, M., Doornenbal, H., Dusar, M., Hummelman, J., Matthijs, J., Menkovic, A., Reindersma, R., Walstra, J., Westerhoff, W. \& Witmans, N., 2014a. Geologisch en hydrogeologisch 3D model van het Cenozoïcum van de Roerdalslenk in Zuidoost-Nederland en Vlaanderen (H3O - Roerdalslenk). Studie uitgevoerd in opdracht van: Afdeling Land en Bodembescherming, Ondergrond, Natuurlijke Rijkdommen van de Vlaamse Overheid; Afdeling Operationeel Waterbeheer van de Vlaamse Milieumaatschappij; Nederlandse Provincie Limburg; Nederlandse Provincie Noord-Brabant; TNO, Geologische Dienst Nederland; VITO/Energyville; in samenwerking met de Belgische Geologische Dienst. Maart 2014. 193 p.

Deckers, J., Broothaers, M., Lagrou, D. \& Matthijs, J., 2014b. The late Maastrichtian to Late Paleocene tectonic evolution of the southern part of the Roer Valley Graben (Belgium). Netherlands Journal of Geosciences, 93/3, 83-93. https://doi.org/10.1017/njg.2014.11

Deckers, J., Vandenberghe, N., Lanckacker, T. \& De Koninck, R., 2016. The Pyrenean inversion phase in northern Belgium: an example of a relaxation inversion? International Journal of Earth Sciences (Geologische Rundschau), 105, 583-593. https://doi.org/10.1007/ s00531-015-1189-8

de Heinzelin, J., 1962. Compte rendu des excursions: descriptions des affleurements. In Symposium sur la stratigraphie du Néogène nordique, Gand 1961. Mémoires de la Société belge de Géologie, série in- $8^{\circ}, 6,183-248$.

Demyttenaere, R., 1989. The post-Paleozoic geological history of northeastern Belgium. Mededelingen van de Koninklijke Academie voor Wetenschappen, Letteren en Schone Kunsten van België, Klasse der Wetenschappen, 51, 51-81.

Demyttenaere, R. \& Laga, P., 1988. Breuken- en isohypsenkaarten van het Belgisch gedeelte van de Roerdal Slenk. Geologische Dienst van België, Professional Paper, 1988/4, 234, 20 p.

De Nil, K., De Ceukelaire, M. \& Van Damme, M., 2020. A reference dataset for the Neogene lithostratigraphy in Flanders, Belgium. Geologica Belgica, 23/3-4, this volume. https://doi.org/10.20341/ $\mathrm{gb} .2020 .021$

Dusar, M., Rijpens, J., Sintubin, M. \& Wouters, L., 2001. Plio-Pleistocene fault pattern of the Feldbiss fault system (southern border of the Roer Valley Graben, Belgium) based on high resolution reflection seismic data. Netherlands Journal of Geosciences / Geologie en Mijnbouw, 80, 79-93. https://doi.org/10.1017/S0016774600023751

Dusar, M., De Ceukelaire, M. \& Walstra, J. 2012. Grensoverschrijdend 3D-model van de Roerdalslenk: stratigrafische interpretatie en correlatie van het Quartair en continentale Neogeen. Koninklijk Belgisch Instituut voor Natuurwetenschappen - Belgische Geologische Dienst, Brussel, 80 p.

Geluk, M.C., 1990. The Cenozoic Roer Valley Graben, Southern Netherlands. Mededelingen Rijks Geologische Dienst, 44-4, 66-72. 
Geluk, M.C., Duin, E.J.Th., Dusar, M., Rijkers, R.H.B., van den Berg, M.W. \& Van Rooijen, P., 1994. Stratigraphy and tectonics of the Roer Valley Graben. Geologie en Mijnbouw, 73, 129-141.

Grosjean, A., 1939. Sur la limite septentrionale du gisement houiller accessible en Campine : les premiers résultats du sondage de Rotem (Schootshei). Bulletin de la Société belge de Géologie, 49, 210-217.

Grosjean, A., 1942. Indices de mouvements tectoniques récents en Campine : leur utilisation pour le tracé superficiel de la faille de Rotem. Bulletin de la Société belge de Géologie, 51, 142-148.

Grosjean, A., 1949. Géologie minière des bassins houillers belges : le gisement de la Campine. Annales des Mines de Belgique, 48, 134-142.

Grützner, C., Fischer, P. \& Reicherter, K., 2016. Holocene surface ruptures of the Rurrand Fault, Germany-insights from palaeoseismology, remote sensing and shallow geophysics. Geophysical Journal International, 204, 1662-1677. https://doi.org/10.1093/gji/ggv558

Gulinck, M., 1960. Un gisement de kiezeloolithes à Lichtaart (Campine). Comparaison avec les cailloutis à kiezeloolithes des collines flamandes. Bulletin de la Société belge de Géologie, 69, 191-210.

Gulinck, M., Geets, S. \& Van Voorthuysen, J.H., 1963. Note sur les sondages du Centre Nucléaire à Mol. Bulletin de la Société belge de Géologie, 72, 283-294.

Gullentops, F., 1963. Etude de divers faciès quaternaires et tertiaires dans le Nord et 1'Est de la Belgique. Excursion O-P, 6e Congrès International de Sédimentologie 1963, Belgique et Pays-Bas, 20 p.

Gullentops, F. \& Huyghebaert, L., 1999. Neogene stratigraphy in the Itter Valley, Roer Valley Graben rim, Belgium. Aardkundige Mededelingen, 9, 143-146.

Gullentops, F. \& Vandenberghe, N., 1995. Toelichtingen bij de geologische kaart van België, Vlaams Gewest: kaartblad 17, Mol [1/50 000]. Belgische Geologische Dienst en Ministerie van de Vlaamse Gemeenschap, Afdeling Natuurlijke Rijkdommen en Energie, Brussel, 65 p.

Hacquaert A. \& Tavernier, R., 1946. Excursions géologiques en Campine. Extrait du compte rendu de la session extraordinaire des Sociétés belges de Géologie (19-26 septembre 1946). Bulletin de la Société belge de Géologie, 55/2-3, Annexe, 452-478.

Houtgast, R.F. \& van Balen, R.T., 2000. Neotectonics of the Roer Valley Rift System, the Netherlands. Global and Planetary Change, 27, 131146. https://doi.org/10.1016/S0921-8181(01)00063-7

Houthuys, R., 2011. A sedimentary model of the Brussels Sands, Eocene, Belgium. Geologica Belgica, 14, 55-74.

Houthuys, R. \& Matthijs, J., 2018. The Hageland hills, legacies of the depositional architecture of the Miocene Diest Sands. In Demoulin, A. (ed.), Landscapes and Landforms of Belgium and Luxembourg. Springer, Cham, World Geomorphological Landscapes, 237-252. https://doi.org/10.1007/978-3-319-58239-9_14

Houthuys, R., Adriaens, R., Goolaerts, S., Laga, P., Louwye, S., Matthijs, J., Vandenberghe, N. \& Verhaegen, J., 2020. The Diest Formation: a review of insights from the last decades. Geologica Belgica, 23/3-4, this volume. https://doi.org/10.20341/gb.2020.012

Kübler, S., 2012. Active tectonics of the Lower Rhine Graben (NW Central Europe) based on new paleoseismological constraints and implications for coseismic rupture processes in unconsolidated gravels. Dissertation zur Erlangung des Doktorgrades der Fakultät für Geowissenschaften der Ludwig-Maximilians-Universität München, Munchen, $161 \mathrm{p}$.

Kuyl, O.S., 1971. Geologische overzichtskaart van Zuid-Limburg. 1/100.000. Rijks Geologische Dienst, Geologisch Bureau voor het Mijngebied, Heerlen.

Langenaeker, V., 1999. Indications for a transpressional late Cretaceous inversion in the Belgian part of the Roer Valley Graben. Aardkundige Mededelingen, 9, 139-142.

Langenaeker, V., 2000. The Campine Basin. Stratigraphy, structural geology, coalification and hydrocarbon potential for the Devonian to Jurassic. Aardkundige Mededelingen, 10, 1-142.

Legrand, R., 1961. L'épéirogenèse, source de tectonique, d'après des exemples choisis en Belgique. Mémoires de l'Institut géologique de l'Université de Louvain, 22, 3-66.

Louwye, S. \& Laga, P., 2008. Dinoflagellate cyst stratigraphy and palaeoenvironment of the marginal marine Middle and Upper Miocene of the eastern Campine area, northern Belgium (southern North Sea Basin). Geological Journal, 43, 75-94. https://doi. org/10.1002/gj.1103

Louwye, S. \& Vandenberghe, N., 2020. A reappraisal of the stratigraphy of the upper Miocene unit $\mathrm{X}$ in the Maaseik core, eastern Campine area (northern Belgium). Geologica Belgica, 23/3-4, this volume. https://doi.org/10.20341/gb.2020.013

Luijendijk, E., Van Balen, R.T., Ter Voorde, M. \& Andriessen, P.A.M., 2011. Reconstructing the Late Cretaceous inversion of the Roer Valley Graben (southern Netherlands) using a new model that integrates burial and provenance history with fission track thermochronology. Journal of Geophysical Research, 116, B06402. https://doi.org/10.1029/2010JB008071

MacEachern, J.A., Raychaudhuri, I. \& Pemberton, S.G., 1992. Stratigraphic applications of the Glossifungites ichnofacies: delineating discontinuities in the rock record. In Pemberton, S.G. (ed.), Applications of Ichnology to Petroleum Exploration: A Core Workshop. Society of Economic Palaeontologists and Mineralogists, Tulsa, OK, Core Workshop Notes, 17, 169-198. https://doi. org/10.2110/cor.92.01.0169

MacEachern, J.A., Pemberton, S.G., Gingras, M.K., Bann, K.L. \& Dafoe, L.T., 2007. Uses of trace fossils in genetic stratigraphy. In Miller, W., (ed.), Trace Fossils: Concepts, Problems, Prospects. Elsevier, Amsterdam, 110-134. https://doi.org/10.1016/B978-0444529497/50133-9

Michon, L., Van Balen, R.T., Merle, O. \& Pagnier, H., 2003. The Cenozoic evolution of the Roer Valley Rift System integrated at a European scale. Tectonophysics, 367/1-2, 101-126. https://doi.org/10.1016/ S0040-1951(03)00132-X

Mourlon, M., 1898. Les dépôts tertiaires de la Campine limbourgeoise. Bulletin de la Société belge de Géologie, 12, 45-58.

Munsterman, D.K., ten Veen, J.H., Menkovic, A., Deckers, J., Witmans, N., Verhaegen, J., Kerstholt-Boegehold, S.J., van de Ven, T. \& Busschers, F.S., 2020. An updated and revised stratigraphic framework for the Miocene and earliest Pliocene strata of the Roer Valley Graben and adjacent blocks. Netherlands Journal of Geosciences, 98, e8. https:// doi.org/10.1017/njg.2019.10

Paredis, A., 1968. Geomorfologische studie van de N.-E. wand van het Kempisch Plateau. Unpublished Master Thesis, K.U.Leuven, Leuven, 159 p.

Patijn, R.J.H., 1963. Tektonik von Limburg und Umgebung. Verhandelingen Koninklijk Nederlands Geologisch-Mijnbouwkundig Genootschap, Geologische Serie, 21/2, 9-24.

Patijn, R.J.H. \& Kimpe, W.F.M., 1961. De kaart van het Carboon oppervlak, de profielen en de kaart van het dekterrein van het Zuidlimburgse mijngebied en de Staatsmijn Beatrix met omgeving. Mededelingen van de Geologische Stichting, Serie C, I-1, 4, 12 p.

Paulissen, E., 1997. Quaternary morphotectonics in the Belgian part of the Roer Graben. Aardkundige Mededelingen, 8, 131-134.

Paulissen, E., Vandenberghe, J. \& Gullentops, F., 1985. The Feldbiss fault in the Maas valley bottom (Limburg, Belgium). Geologie en Mijnbouw, 64, 79-87.

Rossa, H.G., 1986. Upper Cretaceous and Tertiary inversion tectonics in the western part of the Rhenish-Westphalian coal district (FRG) and in the Campine area (N Belgium). Annales de la Société géologique de Belgique, 109, 367-410.

Rypens, J., Sintubin, M. \& Dusar, M., 2004. Geometry and kinematics of the southwestern border fault system of the Roer Valley Graben (NE Belgium). KU Leuven \& Belgische Geologische Dienst, 86 p.

Sels, O., Claes, S. \& Gullentops, F., 2001. Toelichtingen bij de geologische kaart van België, Vlaams Gewest: kaartblad 18 - 10, Maaseik Beverbeek [1/50 000]. Belgische Geologische Dienst en Ministerie van de Vlaamse Gemeenschap, Afdeling Natuurlijke Rijkdommen en Energie, Brussel, $50 \mathrm{p}$.

Sintubin, M., Sels, O. \& Buffel, P., 2001. Late Tertiary fault activity in the southwestern boundary fault system of the Roer Valley Graben: evidences from the Bree area (NE Belgium). Netherlands Journal of Geosciences / Geologie en Mijnbouw, 80, 69-78. https://doi. org/10.1017/S001677460002374X

Stainier, X., 1911. Sur les recherches du sel en Campine. Annales des Mines de Belgique, 16, 117-169.

Stainier, X., 1931. Les failles du bassin de la Campine. Annales des Mines de Belgique, 32, 559-592.

Tys, E., 1980. De geologische struktuur van het steenkoolterrein ten noorden van het ontginningsgebied der Kempense mijnen. Voorlopige synthese en probleemstelling. Geologische Dienst van België, Professional Paper, 179, 45 p.

van den Berg, M.W., 1994. Neotectonics of the Roer Valley rift system. Style and rate of deformation inferred from syn-tectonic sedimentation. Geologie en Mijnbouw, 73, 143-156. 
Vandenberghe, N., Laga, P., Louwye, S., Vanhoorne, R., Marquet, R., De Meuter F., Wouters, K. \& Hagemann, H.W., 2005. Stratigraphic interpretation of the Neogene marine-continental record in the Maaseik well (49W0220) in the Roer valley Graben, NE Belgium. Memoirs of the Geological Survey of Belgium, 52, $39 \mathrm{p}$.

Vandenberghe, N., Wouters, L., Schiltz, M., Beerten, K., Berwouts, I., Vos, K., Houthuys, R., Deckers, J., Louwye, S., Laga, P., Verhaegen, J., Adriaens, R. \& Dusar, M., 2020. The Kasterlee Formation and its relation with the Diest and Mol Formations in the Belgian Campine. Geologica Belgica, 23/3-4, this volume. https://doi.org/10.20341/ gb.2020.014

Vanneste, K., Verbeeck, K., Camelbeeck, T., Paulissen, E., Meghraoui, M., Renardy, F., Jongmans, D. \& Frechen, M., 2001. Surface-rupturing history of the Bree fault scarp, Roer Valley graben: evidence for six events since the late Pleistocene. Journal of Seismology, 5, 329-359. https://doi.org/10.1023/A:1011419408419

Vanneste, K., Verbeeck, K. \& Camelbeeck, T., 2002. Exploring the Belgian Maas valley between Neeroeteren and Bichterweert for evidence of active faulting. Aardkundige Mededelingen, 20, 1-5.

Verhaegen, J., Frederickx, L. \& Schiltz, M., 2020. New insights into the lithostratigraphy and paleogeography of the Messinian Kasterlee Formation from the analysis of a temporary outcrop. Geologica Belgica, 23/3-4, this volume. https://doi.org/10.20341/gb.2020.015

Verbeek, J.W., de Leeuw, C.S., Parker, N. \& Wong, Th.E., 2002. Characterisation and correlation of Tertiary seismostratigraphic units in the Roer Valley Graben. Netherlands Journal of Geosciences / Geologie en Mijnbouw, 81, 159-166. https://doi.org/10.1017/ S0016774600022393

Verhaegen, J., Weltje, G.J. \& Munsterman, D., 2019. Workflow for analysis of compositional data in sedimentary petrology: provenance changes in sedimentary basins from spatio-temporal variation in heavy-mineral assemblages. Geological Magazine, 156/7, 11111130. https://doi.org/10.1017/S0016756818000584

Ziegler, P.A., 1992. North Sea rift system. Tectonophysics, 208/1-3, 5575. https://doi.org/10.1016/0040-1951(92)90336-5

Zijerveld, L., Stephenson, R., Cloetingh, S., Duin, E. \& van den Berg, M.W., 1992. Subsidence analysis and modelling of the Roer Valley Graben (SE Netherlands). Tectonophysics, 208, 159-171. https://doi. org/10.1016/B978-0-444-89912-5.50013-2 